\title{
ZACHĘTA DO UCIECZKI \\ PODCZAS PRZEŚLADOWAŃ (MT 10, 23A) W INTERPRETACJI PATRYSTYCZNEJ
}

Jezus dozwala ucieczkę podczas prześladowań. Tylko Mateusz Ewangelista przekazuje słowa Jezusa w kontekście Jego mowy misyjnej: „Gdy was prześladować będą w tym mieście, uciekajcie do innego" (Mt 10, 23a). Inaczej niż inni synoptycy przedstawia miejsce zalecanej ucieczki. Uczniowie mają uciekać z miasta do miasta, a nie, jak u pozostałych, w góry. Być może decydujący dla tej odmienności jest właśnie kontekst misyjny, obecny u Mateusza, a nieobecny u innych. Mateusz przytacza drugi raz Jezusowy nakaz ucieczki, ale w kontekście już podobnym jak pozostali synoptycy. W tym drugim przypadku tło jest niejako podwójne, mianowicie określone zapowiedzią zburzenia Jerozolimy oraz końca świata. Mateusz i Marek mówią o „ohydzie spustoszenia", ponadto Mateusz ujmuje tę drugą ucieczkę w perspektywie zbliżającego się końca: „I wtedy nadejdzie koniec. Gdy więc ujrzycie ohydę spustoszenia, [...] zalegającą miejsce święte [...], wtedy ci, którzy będą w Judei, niech uciekają w góry” (Mt 24, 14-16); „A módlcie się, żeby ucieczka wasza nie wypadła w zimie albo w szabat” (Mt 24, 20); „A gdy ujrzycie ohydę spustoszenia, [...] wtedy ci, którzy będą w Judei, niech uciekają w góry" (Mk $13,14)$. Łukasz jako jedyny nadaje sytuacji cechy wojny. Jerozolima wówczas będzie otoczona przez wojska. „Wtedy ci, którzy będą w Judei, niech uciekaja w góry; ci, którzy są w mieście, niech z niego uchodzą, a ci, co po wsiach, niech do niego nie wchodzą" (Łk 21,21).

Zajmiemy się interpretacją przez Ojców greckich i łacińskich zaleceń Jezusa w relacji Mt 10, 23a. Rozsyłając uczniów na posługę misyjną, Jezus każe im liczyć się z prześladowaniami i poucza, jak mają postępować. W stosunku do Vetus Latina łacińska wersja logionu Jezusa w Hieronimowej Wulgacie nie uległa zmianie, tak iż można mówić o wczesnym i trwałym zakorzenieniu się następującego sformułowania: „Cum autem persequentur vos in civitate ista, fugite in aliam”. Staraliśmy się odnaleźć, według możliwości, wszystkie dostępne w elektronicznej kwerendzie aluzje Ojców do tego miejsca o charakterze formalnym.

\footnotetext{
* Dr hab. Leon Nieścior OMI, prof. UKSW - kierownik Katedry Teologii Patrystycznej w Instytucie Teologii Systematycznej na Wydziale Teologicznym Uniwersytetu Kard. Stefana Wyszyńskiegow Warszawie; e-mail: 1.niescior@uksw.edu.pl.
} 
Wykorzystaliśmy te odniesienia, w których zalecenie Jezusa zostało zacytowane w całości bądź w istotnej części. Logion Jezusa nie doczekał się jak dotąd studium z zakresu patrystycznej teologii biblijnej ${ }^{1}$.

W przeważającej mierze refleksja Ojców nad Mt 10, 23a dotyczy racji ucieczki w czasie prześladowań. Oddalający się z miejsca represji chrześcijanin mógł łatwo być posądzony o tchórzostwo i dezercję. Wobec masowego zjawiska apostazji i chwiejnej wiary interpretatorzy Ewangelii musieli dokładniej określić kryterium, na podstawie którego ucieczka przed prześladowcą nie była zaparciem się wiary, ale pójściem za radą Jezusa. Czym wolno kierować się uczniowi Chrystusa uciekającemu przed prześladowcami?

1. Posłuszeństwo Słowu. Nasi komentatorzy często podkreślają że taka ucieczka jest po prostu owocem posłuszeństwa Jezusowi. Chrystus „nakazuje świętym uciekać od prześladowców gotowych ich zabić, ponieważ ten, kto w swojej lekkomyślności nie ucieka nie słuchając głosu Pana, zasługuje na naganę"2. W pewnych sytuacjach unikanie represji staje się obowiązkiem. W związku z tym, to nie ucieczka, ale pozostanie staje się naganne.

Literatura martyrologiczna i hagiograficzna opisuje wiele przypadków, w których ucieczkę tłumaczy się posłuszeństwem Słowu Bożemu. Dzisiaj jest wprost niemożliwe ustalić, na ile święci „,uciekinierzy” byli motywowani wprost słowami Ewangelii, a na ile taką formalną motywację przypisali im hagiografowie. Podajemy tylko niektóre przykłady. Biskup Syscji w Panonii, Kwiryn, został pochwycony podczas ucieczki. Gdy go zapytano, dokąd uciekał, odpowiedział, że nie uciekał, ale był posłuszny Panu nakazującemu udać się do innego miasta ${ }^{3}$. Męczenniczki - św. Agapa, Irena i Chionia - według ich Passio, ukrywały się przed represjami zgodnie z zaleceniem Pana, udając się w wysokie góry ${ }^{4}$. Bez zarzutu postapiły męczennice św. Berenika i Prosdokia, które podczas prześladowań za Dioklecjana uciekły z Antiochii do Edessy. Nie uczyniły tego z kobiecej słabości, ale z posłuszeństwa słowu Jezusa w Mt $10,23 \mathrm{a}^{5}$. Z rady Jezusa skorzystał św. Jan Jałmużnik, który w $611 \mathrm{r}$. został biskupem Aleksandrii i zasłynął z dzieł miłosierdzia. Podczas inwazji Persów na Egipt w 616 r. opuścił Aleksandrię. Podczas podróży morskiej zachorował i - według Leoncjusza z Neapolu - zatrzymał się na Cyprze, swojej ojczystej wyspie, gdzie też zmarł ${ }^{6}$.

\footnotetext{
${ }^{1}$ Od strony biblijnej zob. J.M. McDermott, Matth 10:23 in context, „Biblische Zeitschrift” 28 (1984) fasc. 2, 230-240.

${ }^{2}$ Clemens Alexandrinus, Fragmenta varia 56, ed. O. Stählin - L. Früchtel - U. Treu, GCS 17, Berlin $1970^{2}, 226$, tłum. własne.

${ }^{3}$ Por. Passio Quirini 2, Acta Martyrum, ed. Th. Ruinart, Ratisbonae 1859, 522.

${ }^{4}$ Por. Passio Agapes et Eirenes et Chiones 2, ed. H. Musurillo, w: The Acts of the Christian Martyrs, Oxford 1972, 280.

${ }^{5}$ Por. Joannes Chrysostomus, De sanctis Bernice et Prosdoce 5, PG 50, 636.

${ }^{6}$ Por. Leontius Neapolitanus, Vita Joannis Eleemosynarii episcopi Alexandrini, Léontios de
} 
Posłuszeństwem wobec nakazów Ewangelii tłumaczy się również św. Atanazy Aleksandryjski. Powołuje się na Mt 10, 23a jako rację swojej ucieczki do innych miejsc, gdy był prześladowany przez fanatycznych zwolenników arianizmu ${ }^{7}$. Apologie do Konstancjusza napisał po trzecim wygnaniu z Aleksandrii, w 2. poł. 357 r. Stwierdza tam, że nie tylko Ewangelia, ale w ogóle Pismo Święte, dozwala ucieczkę. Zalecenie Jezusa poprzedza praktyka stosowania azylu w Starym Testamencie (por. Wj 21, 13; Lb 35, 12) ${ }^{8}$. Biskup Aleksandrii usprawiedliwia ucieczkę i prosi cesarza o wstrzymanie dalszego prześladowania zwolenników wiary nicejskiej. Zreszta, to ścigający powinien się tłumaczyć, a nie ścigany, bo ten pierwszy ma zamiar zabicia, a drugi chce po prostu uniknąć śmierci 9 .

Jak widać, nasi komentatorzy nie widzą przeszkód, żeby uznać za prześladowców heretyków dyskryminujących katolicką wiarę i radę Jezusa w Mt 10, 23a odnieść do uciekających przed nimi. Dezaprobata dla fałszywej wiary nie pozwala im symetrycznie uznać za prześladowanych także innowierców, którzy ponoszą cierpienie za swoje przekonania. Ich zdaniem heretyk nie może być męczennikiem, ponieważ nie wierzy w prawdziwego Chrystusa. Skoro nie jest $\mathrm{Mu}$ posłuszny, to i nie może w sposób właściwy wypełnić nakazu ucieczki przed prześladowcami. Duchowny ariański Demofil, zobowiązany przez cesarza do opuszczenia Konstantynopola, zaczął odprawiać nabożeństwa tuż za murami miasta, powołując się na Mt 10, 23a. Opisujący to zdarzenie Sokrates Scholastyk zaznacza, że „opacznie pojmował sens wypowiedzi ewangelicznej, nakazującej apostołom uciekać przed światowym zgiełkiem, a szukać niebieskiej Jeruzalem"10.

W polemice $\mathrm{z}$ donatystami Augustyn zwraca uwagę na fakt, że zalecenie Jezusa, aby uciekać z miasta do miasta, zostało dane Apostołom jako prawdziwym głosicielom Ewangelii, a nie heretykom czy schizmatykom. Zresztą, tych nikt nie prześladuje. Brak prześladowań pokazuje, że nie są owcami posłanymi między wilki. Nie są prawdziwą owczarnią Chrystusa ${ }^{11}$. Biskup Hippony wyciaga z Mt 10, 23a wniosek, że nie zabraknie aż do końca świata miejsc schronienia dla uczniów Jezusa. Gdyby zabrakło, Jezus nie zalecałby uciekać z miasta do miasta. Jeśli brakuje, to tylko dlatego, że ci, którym brakuje, nie są

Néapolis, Vie de Syméon le Fou et Vie de Jean de Chypre, ed. A.J. Festugière - L. Rydén, Paris 1974, 402.

${ }^{7}$ Por. Athanasius Alexandrinus, Epistula encyclica 5, ed. H.G. Optiz, w: Athanasius Werke 2/1, Berlin - Leipzig 1935, 174.

${ }^{8}$ Por. tenże, Apologia de fuga sua 11, ed. H.G. Optiz, w: Athanasius Werke 2/1, Berlin - Leipzig $1935,76$.

${ }^{9}$ Por. tamże 8, ed. Optiz 2/1, 73 .

${ }^{10}$ Socrates Scholasticus, HE V 7, PG 67, 575A, thum. S. Kazikowski: Sokrates Scholastyk, Historia Kościoła, Warszawa 1972, 349. Por. Sozomenus, HE VII 5, PG 67, 1425, thum. S. Kazikowski: Hermiasz Sozomen, Historia Kościoła, Warszawa 1989, 459-460.

${ }^{11}$ Por. Augustinus Hipponensis, Contra litteras Petiliani II 19, 43, ed. M. Petschenig, CSEL 52, Vindobonae 1909, 44. 
naprawdę Jego uczniami. Ci, którzy ich rzekomo prześladują, katolicy, nie są ich osobistymi prześladowcami, ale ich błędów, a więc ,prześladowcami ich prześladowców" ${ }^{\prime 2}$. Okolicznością takiej polemiki była radykalna postawa biskupa donatystów Gaudencjusza, który zamknął się w kościele w Thamugadi i groził spaleniem się razem ze świątynią i swoimi zwolennikami. Egzekwujący bowiem dekrety cesarskie trybun Dulcycjusz żądał powrotu donatystów do jedności z katolikami ${ }^{13}$.

Tak więc w przekonaniu Ojców słowa Jezusa w Mt 10, 23a nie odnoszą się do innowierców. Sprawcy represji nie są faktycznie prześladowcami w rozumieniu Ewangelii. Tak oceniają zwłaszcza ci, którzy występują przeciwko donatystom chętnie uznającym się za prześladowanych. Represje nie są faktycznie prześladowaniem, bo jeśli nawet istnieją, to z powodu fałszywej, a nie prawdziwej wiary. Natomiast represjonowani nie są prawdziwymi uczniami Chrystusa. Posłuszeństwo słowom Jezusa o ucieczce ma sens, jeśli słucha się także innych Jego słów.

2. Zrządzenie Boga. Polecając ucieczkę, Bóg zapewnia środki ją umożliwiające. Zrządzenie Boga, który w swojej Opatrzności chroni człowieka przed przedwczesną śmiercią, uprzedza jego odpowiedź na zamysł Boży. Orozjusz opisuje dewastację Hiszpanii przez germańskich najeźdźców, którymi wspomagał się syn Konstantyna Wielkiego, Konstancjusz. Ofiarą tych najazdów padali także chrześcijanie. Interpretując teologicznie wydarzenia historyk podkreśla, że to Miłosierny Bóg, powodowany tą samą łaskawością, przez którą wskazał w słowach Jezusa na możliwość ucieczki, tak zrządził, że wśród samych barbarzyńców znaleźli się życzliwi ludzie, obrońcy chrześcijan, kupcy, którzy umożliwili ucieczkę wraz $\mathrm{z}$ dobytkiem ${ }^{14}$. $\mathrm{Z}$ jednej więc strony chrześcijanin słucha Ewangelii, z drugiej strony Bóg planuje losy ludzkie i im towarzyszy.

Na zrządzenie Boże i opatrznościowy zbieg okoliczności powołuje się Dionizy, biskup Aleksandrii, który opuścił siedzibę biskupią podczas represji za cesarza Decjusza w 251 r. Chciał pozostać na miejscu, oczekując nadejścia śledczych wysłanych przez prefekta Egiptu, ale po czterech dniach odszedł wraz ze swoja rodzina, kiedy sam „Bóg kazał uchodzić i gdy w cudowny sposób drogę [...] otworzy ${ }^{\prime 15}$. W drodze został zatrzymany przez grupę żołnierzy, ale powiadomieni przez wieśniaka, przypadkowego świadka zdarzenia, weselnicy z pobliskiej miejscowości przepędzili żołnierzy i nakazali swemu biskupowi uciekać ${ }^{16}$. Dionizy Wielki został później skazany na banicję w pustynne regiony Libii.

${ }^{12}$ Tenże, Contra Gaudentium I 18, 19, ed. M. Petschenig, CSEL 53, Vindobonae 1910, 214, tłum. własne.

${ }^{13}$ Por. tamże I 1, 1, CSEL 53, 201-202.

${ }^{14}$ Por. Orosius, Historiarum adversum paganos lib.VII 41, 1-6, PL 31, 1167-1168.

${ }^{15}$ Eusebius Caesariensis, HE VI 40, 2, ed. E. Schwartz, GCS 9/2, Leipzig 1908, 596, thum. A. Lisiecki: Euzebiusz z Cezarei, Historia kościelna, POK 3, Poznań 1924, 292.

${ }^{16}$ Por. tamże VI 40, 4-9, GCS 9/2, 596, POK 3, 292-293. 
Zamysły Boże są jednak nieraz trudne do odgadnięcia i mogą stać się przedmiotem dyskusyjnych spekulacji, czasem manipulacji. Tak oto Tertulian interpretuje losy pewnego chrześcijanina:

„Rutilius, święty męczennik, kilkakrotnie uciekał przed prześladowaniem przenosząc się z miejsca na miejsce i tam, gdzie uważał to za właściwe, wykupywał się od niebezpieczeństwa pieniędzmi. Gdy uznał, że jest już całkowicie bezpieczny, znienacka schwycono go i postawiono przed namiestnikiem i torturowano - ja uważam, że była to kara za ucieczkę - następnie skazano na spalenie na stosie, a dzięki miłosierdziu Bożemu zniósł męki, których przedtem unikał. Cóż innego zechciał nam Pan ukarać w tym fakcie, jak nie to, że nie wolno uciekać przed prześladowaniem, ponieważ na nic się zda jakakolwiek ucieczka, o ile inna będzie wola Boża?"17.

To samo miłosierdzie Boże, które według Orozjusza chroniło chrześcijan przed śmiercią, według Tertuliana obdarzyło chwiejnego Rutiliusa łaską męczeństwa. Szczególnie okrutna śmierć chrześcijanina jest dla Kartagińczyka przejawem kary za ucieczkę. Tertulian-montanista pozostawał przeciwnikiem ucieczki przed prześladowcami, o czym jeszcze będzie mowa. Uważał, że jeśli Pan przyzwolił na ucieczkę, to uczynił to jednostkowo w stosunku do Apostołów, ale w ogólności nie jest Jego wolą, aby uciekać podczas prześladowann ${ }^{18}$. Niemniej godna uwagi pozostaje próba godzenia represji doznawanych przez chrześcijan z Opatrznością i Miłosierdziem Boga.

3. Postawa Chrystusa. Typowym dla Augustyna argumentem za godziwością ucieczki podczas prześladowań jest przykład Jezusa. W nawiązaniu do wybiegu Abrahama, który roztropnie zataił przed Egipcjanami, że jest mężem Sary (por. Rdz 12, 11-13), Augustyn broni w dziele Przeciw Faustusowi praktyki ucieczki przed niebezpieczeństwem, odwołując się do przykładu Mistrza:

„Mając bowiem moc oddania swojej duszy nie oddał jej kiedy indziej, ale kiedy zechciał i jako dziecko uciekł do Egiptu niesiony przez rodziców”19.

Z rodzicami Jezus uciekł do Egiptu nie pod wpływem słabości, ale by dać przykład czujności. Odtąd żaden jego sługa nie powinien uważać ucieczki za rzecz haniebna, skoro jest ona rozwiązaniem zgodnym z Mt 10, 23a. Podobnie Jezus uczył uczniów roztropności, kiedy nie zdradził im do końca swoich zamiarów przybycia do Jerozolimy na Święto Namiotów. Gdy namawiali Go do tego,

${ }^{17}$ Tertullianus, De fuga in persecutione 5, ed. J.J. Thierry, CCL 2, Turnhout 1954, 1142, thum. T. Kołosowski: Tertulian, O ucieczce podczas prześladowań, w: Tertulian, Wybór pism, III, PSP 65, Warszawa 2007, 161.

${ }^{18}$ Por. tamże VI 1, CCL 2, 1142-1143.

${ }^{19}$ Augustinus Hipponensis, Contra Faustum XXII 36, ed. J. Zycha, CSEL 25, Vindobonae 1891, 630, tłum. J. Sulowski: Św. Augustyn, Przeciw Faustusowi. Księi XXII-XXIII, PSP 56, Warszawa 1991, 33. Wypowiedź Augustyna przytacza dosłownie Beda Czcigodny. Por. Beda Venerabilis, In Lucae evangelium expositio I in 4, 12, ed. D. Hurst, CCL 120, Turnhout 1960, 97. 
odpowiedział oględnie: „Mój czas jeszcze nie nadszedł” (J 7, 6). Dał przykład czujności względem nieprzyjacielskich zasadzek. On zawsze ma władzę, by uniknąć podstępu wroga, jeśli tylko chce, podczas gdy oni nie mają ${ }^{20}$.

„Również na święta nie poszedł jawnie, ale ukradkiem, choć kiedy indziej otwarcie przemawiał do Żydów rozwścieczonych z niezwykle wrogim nastawieniem umysłu słuchaczy, ale nie mogących na Niego podnieść ręki, ponieważ jeszcze nie nadeszła Jego godzina. Zreszta, nie dlatego, żeby nadejście tej godziny z konieczności zmusiło Go do tego, by poniósł śmierć, ale w niej, jako że nadeszła właściwa pora, pozwolił się zabić. On, który okazywał potęgę Bożą otwarcie nauczając i gromiąc, równocześnie nie pozwolił, żeby wściekłość jego wrogów cokolwiek mogła zrobić przeciwko Niemu"21.

Biskup Hippony akcentuje pełną suwerenność Chrystusa, który mógł we wszechmocnym Bóstwie znaleźć wiele innych sposobów, by zapobiec niebezpieczeństwu i swojej przedwczesnej śmierci. Ze względów pedagogicznych wybrał sposób dostępny także Jego uczniom, aby oni też zdołali się uratować przed niepożądaną śmiercią.

Powyższą wypowiedź Augustyna przytacza formalnie Beda Czcigodny ${ }^{22}$, a gdzie indziej dodaje własny komentarz szukając sensu eklezjalnego w ucieczce Świętej Rodziny do Egiptu. Zbiegnięcie to oznacza, że wybrani powinni częściej uciekać przed nieprawością ludzi złych, nawet za cenę skazania na wygnanie. Zdarzenie opowiedziane w Ewangelii pozostaje dla Bedy figura przyszłych losów Kościoła. Herod prześladujący Dziecię jest obrazem wszelkich jego prześladowców. Pan i Bóg dał swoim wiernym przykład, aby nie wahali się co do ucieczki, jeśli nadarzy się sposobność. Sam tak postąpił, zanim zalecił takie postępowanie ${ }^{23}$.

Również Piotr Chryzolog rozpatruje ucieczkę do Egiptu Maryi i Józefa z Jezusem. Gdyby Jezus nie znalazł tam schronienia, nie dokonałoby się odkupienie przez Jego późniejszą mękę i śmierć, bo zostałby przedwcześnie zabity przez Heroda. Człowiek nie otrzymałby wielu dóbr duchowych. Kaznodzieja podaje jeszcze inny argument. Chrystus przyjął nas w siebie, aby dać nam siebie; doznał naszych cierpień, aby je usunąć. Dlatego też ucieka, ,aby dopuścić i nasze ucieczki podczas prześladowań". Ucieka Pan, aby sługa nie uznawał ucieczki za rzecz niegodną. Ucieczka Jezusa z Judei do Egiptu jest też obrazem odrzucenia Go przez synagogę, a przyjęcia przez ludy pogańskie, z których powstanie Kościół ${ }^{24}$. Chryzolog wychodzi więc poza motyw nauki

${ }^{20}$ Por. Augustinus Hipponensis, Sermo 133, 7, PL 38, 741-742.

${ }^{21}$ Tenże, Contra Faustum XXII 36, CSEL 25, 630, PSP 56, 33.

${ }^{22}$ Por. Beda Venerabilis, In Lucae evangelium expositio I in 4, 12, CCL 120, 97.

${ }^{23}$ Por. tenże, Homeliarum evangelii lib. I 10, ed. D. Hurst, CCL 122, Turnhout 1955, 69.

${ }^{24}$ Petrus Chrysologus, Collectio sermonum 151, 4-8, ed. A. Olivar, CCL 24B, Turnhout 1975, 945-946, thum. własne. 
i przykładu obecny w ucieczce Chrystusa. Wskazuje na motyw odkupienia, zgodnie ze znaną zasadą: „co przyjął, to odkupił”.

Tymczasem, zastanawiając się nad odejściem Jezusa „w miejsce bezludne" na wieść o śmierci Jana Chrzciciela (por. Mt 14, 13), Hieronim dostrzega kilka możliwych jego motywów, do których jeszcze nawiążemy. Wskazuje też na wzgląd ekonomii zbawienia, która każe wybrać odpowiedni moment dla każdego wydarzenia. Dlatego Chrystus odłożył

„swój zgon na dzień Paschy, kiedy ze względu na obrzęd religijny ma być złożony na ofiarę baranek, a odrzwia wierzących mają być pomazane krwią (por. Wj 12, 6-7). [...] Umiejętnie też ewangelista nie powiedział: «uciekł na miejsce bezludne», ale «oddalił się», tak że prześladowców raczej unikał niż się obawiał"25.

Niezależność, posłuszeństwo Ojcu i godność, z jaką Jezus przyjmuje wszystko, każe dobrać właściwe słowo dla Jego decyzji odejścia na miejsce odosobnione.

4. Słabość ludzka. Opisane w Ewangelii „ucieczki” Jezusa przed niebezpieczeństwem są wyrazem Jego kenozy, przyjęcia wszystkiego co ludzkie, $\mathrm{z}$ wyjątkiem grzechu. Jeśli Jezus ukrywał się przez jakiś czas, to nie ze względu na siebie, ale ze względu na słabych uczniów ${ }^{26}$. On wziął na siebie ludzkie ucieczki wynikające ze słabości natury. Nasi komentatorzy odwołują się dość często do motywu ludzkiej słabości nakazującej uciekać przed niebezpieczeństwem, któremu nie da się zapobiec inaczej.

W jednej z aluzji do Mt 10, 23a Beda Czcigodny zwraca uwagę na dwa główne powody, dlaczego wierni ukrywają się podczas prześladowań. Postępują tak zgodnie z zaleceniem Jezusa: ,czy to dlatego, że nie śmią, czy że nie mają zgody na to, by ujawniać się"27. Czynią to zatem albo z obawy przed zaparciem się wiary, albo z uległości Jego słowu, innymi słowy, z pokory i szacunku względem Niego albo posłuszeństwa. Drugi wymieniony przez Bedę powód omówiliśmy na początku, obecnie zajmujemy się pierwszym.

Asteriusz Sofista łączy chrześcijańską ucieczkę z przemijalnością obecnego świata. Kościół jest namiotem rozbitym przez Chrystusa. Zalecając ucieczkę z miasta do miasta, Chrystus nawiązuje do pielgrzymiego charakteru obecnej egzystencji Kościoła. Zmiana miejsca nie może jednak prowadzić do zmiany obyczajów. Podczas tej migracji należy strzec dotychczasowych obyczajów, aby nie była ona przejściem z pobożności do bezbożności ${ }^{28}$.

${ }^{25}$ Hieronymus, Commentarii in evangelium Matthaei II in 14, 13, ed. D. Hurst - M. Adriaen, CCL 77, Turnhout 1969, 120, thum. J. Korczak: Hieronim, Komentarz do Ewangelii wedlug św. Mateusza, ŹMT 46, Kraków 2008, 95.

${ }^{26}$ Por. Augustinus Hipponensis, Sermo 133, 7, PL 38, 741-742.

${ }^{27}$ Beda Venerabilis, In proverbia Salomonis lib. III in 28, 28, ed. D. Hurst, CCL 119B, Turnhout 1983, 138, tłum. własne.

${ }^{28}$ Por. Asterius Sophista, Commentarii in Psalmos 26, 7, ed. M. Richard, Asterii sophistae commentariorum in Psalmos quae supersunt, Oslo 1956, 240. 
Rozpatrywaną rację ucieczki trafnie ukazał Orygenes:

„Jeśli jednak poczujesz się słaby w czasie prześladowania, jeśli stwierdzisz, że ze względu na swą cielesną słabość nierówną walkę toczysz przeciwko okrucieństwu tyrana, wolno ci podczas wojskowej służby Chrystusowej udzielić miejsca gniewowi i uciekać z miejsca na miejsce; nie otrzymałeś tutaj rozkazu walki. To również zostało określone w prawach Chrystusa: «Jeśli was będą prześladować w tym mieście [...]» (Mt 10, 23). Najważniejsza bowiem sprawą jest, abyś nie wyrzekł się Jezusa, którego raz wyznałeś. Nie ulega wszak wątpliwości, że wyznaje Go ten, kto ucieka dlatego właśnie, aby się Go nie wyrzec. Kto więc jest bojaźliwy i trwożliwy w sercu, niechaj odejdzie z obozu, niechaj wróci do swego domu, aby innym nie dawał przykładu swego strachu i bojaźni”'29.

Nie jest obowiązkiem chrześcijanina pozostawać na miejscu represji, natomiast jest obowiązkiem pozostać przy wierze. Roztropność każe wziąć pod uwagę dobro wyższe i nie trzymać się sztywno jednego rodzaju postawy. Próba zdobycia się na odwagę, której wewnątrz nie ma, może zakończyć się tragicznie: upadkiem własnym i zgorszeniem innych.

Doradzając ucieczkę, Jezus wychodzi naprzeciw ludzkiej słabości przejawiającej się w skłonności do lęku ${ }^{30}$. Dokonując realnej oceny natury, zaleca ucieczkę, aby ktoś pragnący chwały męczeństwa nie wystawiał się zbędnie na próbę. Może nie zdołałby przetrzymać ze względu na ,wątłe ciało lub zbyt słabego ducha". Mamy zabiegać o to, co szlachetne, ale na miarę naszych możliwości ${ }^{31}$. Uczniowie Jezusa mogą lękać się utraty życia podczas prześladowań. Słowa Jezusa w Mt 10, 23a są nie tylko wyrazem znajomości ludzkiej natury, ale i w jakiś sposób jej głosem. To pod jej wpływem Jezus doznawał trwogi w Ogrójcu i prosił swoich uczniów o wsparcie ${ }^{32}$. Również i męczennicy nie byli wolni od lęku przed śmiercią. Lękali się jej podobnie jak Jezus w Ogrójcu, jak bracia ich w wierze, ale przedłożyli „,wolę Bożą nad swoją naturalną wolę pod wpływem pobożności i posłuszeństwa"33.

Dostrzegamy u naszych komentatorów pewne rozdwojenie w uznawaniu słabości ludzkiej jako motywu ucieczki przed prześladowaniami. Wyrazem tej

${ }^{29}$ Origenes, Homiliae in librum Iudicum IX 1, ed. W.A. Baehrens, GCS 30, Leipzig 1921, 519, tłum. S. Kalinkowski: Orygenes, Homilie o Księdze Jozuego, w: Orygenes, Homilie o Księgach Liczb, Jozuego, Sędziów, PSP 34/2, Warszawa 1986, 182. Por. Apponius, In Canticum canticorum expositio X 20 in 7, 3, ed. B. de Vregille - L. Neyrand, CCL 19, Turnhout 1986, 245.

${ }^{30}$ Por. Ambrosius Autpertus, Expositio in Apocalypsin IV in 7, 13, ed. R. Weber, CCM 27, Turnhout 1975, 318.

${ }^{31}$ Ambrosius Mediolanensis, De officiis ministrorum I37, 187, ed. M. Testard, CCL 15, Turnhout 2000, 70, thum. K. Abgarowicz: Św. Ambroży, O obowiqzkach duchownych, Warszawa 1967, 87.

32 Por. tenże, Explanatio psalmorum XII in 39, 16, ed. M. Petschenig, CSEL 64, Vindobonae 1919, 220.

${ }^{33}$ Facundus Hermianensis, Pro defensione trium capitum ad Iustinianum lib. III 4, 23, ed. I.M. Clément - R. Vander Plaetse, CCL 90A, Turnhout 1974, 84, tłum. własne. 
ambiwalencji jest wahanie, z jakim używają słowa ,ucieczka” (łac. fuga). Na przykład Cyprian świadomie unika go na rzecz „odejścia” (secessio) ${ }^{34}$. Tym bardziej autorzy wstrzymuja się przed użyciem słowa „ucieczka” w stosunku do Jezusa. Bardzo często, niemal jako topos, powtarza się zastrzeżenie, że chrześcijanin nie ucieka $\mathrm{z}$ lęku przed prześladowcami. Z drugiej strony, mówi się o jego podleganiu ludzkiej słabości, a więc i lękowi. Według naszej orientacji, żaden z Ojców nie wyjaśnił tego zagadnienia w kontekście Mt 10, 23a. W ich duchu możliwe jest takie wytłumaczenie, że chrześcijanin nie kieruje się lękiem jako decydującym motywem postępowania, natomiast liczy się z nim i unika sytuacji, w których lęk może wziąć górę.

5. Roztropność. Doświadczenie słabości, która każe chrześcijaninowi realnie oceniać własne siły i nie narażać się lekkomyślnie na zbyt wielkie niebezpieczeństwo, prowadzi do czujnej rozwagi. Słuszną racją ucieczki staje się roztropność.

Orygenes sprzeciwia się nierozważnemu narażaniu się na prześladowania:

„O ile możemy, powinniśmy uchodzić przed prześladowcami i unikać zasadzek, które ze względu na Słowo nas czekają. [...] Gdy przychodzi na nas próba, wobec której jesteśmy bezsilni, należy ją podjąć bardzo godnie i odważnie; gdy zaś można jej uniknąć, nie uczynić tego jest lekkomyślnością"35.

Taką roztropność wykazywał sam Chrystus, gdyż nie tylko tak nauczał, ale i sam starał się nie narażać nierozważnie, nierozsądnie i nie w porę na niebezpieczeństwa ${ }^{36}$.Ta sama roztropność może podpowiadać różne rozwiązania:

„Nie zawsze należy unikać niebezpieczeństw i nie zawsze im się przeciwstawiać; trzeba jednak mądrości w Chrystusie, aby osądzić, jaki czas wymaga wycofania się, a jaki gotowości do walki bez usuwania się, a tym bardziej bez ucieczki" ${ }^{37}$.

Dodajmy, że szkołę roztropności otrzymał Orygenes od swojej matki, kiedy jego gorącemu pragnieniu męczeństwa po uwięzieniu ojca z powodu wiary, przeszkodziła w ten sposób, że ,schowała wszystkie jego ubrania, i tak zmusiła do pozostania $\mathrm{w}$ domu" 38 .

Do wzoru Chrystusa roztropnie unikającego zagrożeń nawiązuje również Hieronim. Odnosząc się do Jego odejścia po śmierci Jana Chrzciciela „na miejsce bezludne" (por. Mt 14, 13), pisze:

${ }^{34}$ Por. Cyprianus Carthaginensis, Epistula 20, 1, PL 4, 262, tłum. W. Szołdrski: Św. Cyprian, Listy, PSP 1, Warszawa 1969, 73.

${ }^{35}$ Origenes, Commentarii in Matthaeum X 23, ed. E. Klostermann - E. Benz, GCS 40, Leipzig 1935, 31, tłum. K. Augustyniak: Orygenes, Komentarz do Ewangelii wedlug św. Mateusza, ŹMT 10, Kraków 1998, 72.

${ }^{36}$ Por. tenże, Contra Celsum I 65, ed. M. Borret, SCh 132, Paris 1967, 256, thum. S. Kalinkowski: Orygenes, Przeciw Celsusowi, Warszawa 1986², 82.

${ }^{37}$ Tenże, Commentarii in Matthaeum XVI 1, GCS 40, 463, ŹMT 10, 276.

${ }^{38}$ Eusebius Caesariensis, HE VI 2, 5-6, GCS 9/2, 520, POK 3, 252. 
„Albo też dlatego się oddalił, aby dać nam przykład unikania lekkomyślności, jaka jest udziałem dobrowolnie się wydających, ponieważ nie wszyscy z taką samą stałością trwają na mękach, z jaką narażają się na tortury"39.

Strydończyk podaje też starotestamentalny przykład proroka Uriasza, prorokującego w zgodzie z Jeremiaszem. Uriasz uciekł do Egiptu, bo przeląkł się Jojakima, króla judzkiego, gdy ten chciał go zabić (por. Jr 26, 20-21). Powołując się na Mt 10, 23a, Strydończyk uznaje jego czyn za oznakę nie tyle słabości, co roztropności, która zabrania wystawiać się niepotrzebnie na niebezpieczeństwo $^{40}$. Zdaniem Tertuliana, jak lepiej jest ożenić się „niż płonąć” (1Kor 7, 9), tak lepiej podczas prześladowań uciekać z miasta do miasta aniżeli zostać pojmanym i wyrzec się wiary pod wpływem tortur ${ }^{41}$.

Dla odpowiedzi na pytanie, czy grzeszy ten, kto ucieka podczas prześladowań, Anastazy Synajski wprowadza rozróżnienie pomiędzy zagrożeniem dla duszy i dla ciała. Jeśli mamy do czynienia ze zgubą zagrażającą duszy, to wolno uciec ze względu na to, co wystawia nas na pokuszenie. Jeśli z kolei chodzi o szkodę zagrażającą ciału, to nie zachodzi potrzeba ucieczki, gdyż Chrystus wspomoże nas $w$ wytrwałości ${ }^{42}$. Anastazy wydaje się sądzić podobnie jak inni. Groźba zaparcia się wiary z powodu lęku podpada pod kategorię zagrożenia dla duszy i zdaje się w jego przekonaniu usprawiedliwiać ucieczkę.

W mowie ku czci św. Genezjusza z Arles czytamy, że święty ten jako katechumen, pochwycony nad Rodanem podczas prześladowań za Dioklecjana, rzucił się do rzeki, przepłynął na drugi brzegi i tam się ukrywał. Chodził od miasta do miasta, trzymając się sąsiedztwa rzeki. Ponownie został schwycony i stracony. Strumienie krwi dopełniły sakramentu chrztu. Autor mowy wskazuje na nadprzyrodzoną celowość jego postępowania. Mianowicie uciekał nie dlatego, by uniknąć chwalebnej śmierci, ale po to, by dopełnić wszystkiego, czego wymaga „stan męczeński” (ordo martyrii) ${ }^{43}$. Powołując się w tym kontekście na Mt 10, 23a, kaznodzieja zdaje się wskazywać na rozwage jako warunek prawdziwego męczeństwa. Świadek Chrystusa nie szuka w nim swojej woli, nie poddaje się pochopnie prześladowcom, lecz daje sobie i losowi pewien czas, by spełniły się wyroki boskie. Nie mając pewności, czego chce Bóg, kieruje się ludzką roztropnością.

6. Ufność względem Boga. Tłumacząc racje chrześcijańskiej ucieczki, Augustyn powołuje się kilkakrotnie na postępowanie Pawła. Apostoł sam wspomina

${ }^{39}$ Hieronymus, Commentarii in evangelium Matthaei II in 14, 13, CCL 77, 120, ŹMT 46, 95.

${ }^{40}$ Por. tenże, In Hieremiam prophetam lib. V in 26, 20n., ed. S. Reiter, CSEL 59, Vindobonae 1913, 330 .

${ }^{41}$ Por. Tertullianus, Ad uxorem I 3, 4, ed. E. Kroymann, CCL 1, Turnhout 1954, 375-376.

${ }^{42}$ Por. Anastasius Sinaita, Quaestiones et responsiones 75, ed. J.A. Munitiz - M. Richard, CCG 59, Turnhout 2006, 126-127.

${ }^{43}$ Por. Eusebius Gallicanus, Collectio homiliarum LVI 6, ed. F. Glorie, CCL 101A, Turnhout 1971, 653. 
o pewnym zdarzeniu. Mianowicie namiestnik króla Aretasa w Damaszku kazał strzec miasta, aby go pojmać. Wtedy Paweł został spuszczony w koszu przez okno za mur miejski (por. 2Kor 11, 32-33). W Dziejach Apostolskich mówi się, że to Żydzi chcieli zabić Pawła i strzegli bramy miasta w dzień i w nocy. Uczniowie pomogli Pawłowi uciec w powyższy sposób (por. Dz 9, 23-25).

Dłuższy wywód Augustyna na temat ucieczki Pawła znajdujemy w piśmie O pracy mnichów. W świetle słów Jezusa o Opatrzności Bożej (por. Mt 6, 2628) biskup Hippony zajmuje się ,ucieczką od życia” mnichów unikających pracy fizycznej. Wcześniej jednak podejmuje problem ucieczki przed prześladowaniem. Czy Apostoł nie powinien raczej „oczekiwać schwytania, żeby go Bóg wyzwolił, jak trzech młodzieńców ze środka ognia (por. Dn 3, 21-24. 46-50)"? Można by postawić

„uczniom Pana uciekającym przed prześladowaniami tego rodzaju pytanie, dlaczego raczej nie pozostali na miejscu i, wezwawszy Boga, nie zostali przez niego wybawieni w cudowny sposób tak jak Daniel od lwów".

Augustyn odpowiada:

„,̇e nie powinni wystawiać Boga na próbę, lecz On, jeśli chciałby, cudownie ich uratuje wtedy, gdy oni sami będą już zupełnie bezsilni. Skoro zaś dał im możliwość ucieczki, chociażby nawet przez nią zostali uwolnieni, stało się to tylko dzięki Niemu samemu" "44.

W dziele Przeciw Faustusowi pogłębia temat ucieczki Pawłowej:

„Jest natomiast doktryną pewną, że kiedy człowiek ma jakieś wyjście, nie powinien kusić Pana, Boga swego".

Uciekając Paweł nie zwątpił w pomoc i opiekę Boga, nie stracił ufności względem Niego. Nie chciał jednak kusić Boga, skoro istniała możliwość ucieczki:

„Onże sam uciekając i ukrywając się uczył, jak powinna się zachować ludzka słabość, żeby nie ośmieliła się kusić Boga, kiedy znajduje wyjście, by uniknąc tego, przed czym powinna się strzec"45.

Człowiek nie sięga po środki nadprzyrodzone i nie szuka interwencji Boga, jeśli ma pod ręką środki naturalne do rozwiązania problemu. Inne postępowanie będzie kuszeniem Boga. Jeśli uzna się, że najlepszym rozwiązaniem pozostaje uniknąć śmierci, naturalnym sposobem jej uniknięcia jest ucieczka przed prześladowcą. Ucieczka ta nie koliduje z postawą ufności wobec Boga, wprost przeciwnie, stanowi jej wyraz. Uciekający chrześcijanin dostrzega w nadarzającej się sposobności do ucieczki znak Opatrzności Bożej.

${ }^{44}$ Augustinus Hipponensis, De opere monachorum 27, ed. J. Zycha, CSEL 41, Vindobonae 1900, 593, thum. R. Szaszka: Św. Augustyn, O pracy mnichów, w: Św. Augustyn, Pisma monastyczne, ŹM 27, Kraków 2002, 250-251.

${ }^{45}$ Tenże, Contra Faustum XXII 36, CSEL 25, 630, PSP 56, $32-33$. 
Uciekinier może przejawiać zaufanie Bogu w różny sposób. Ucieczka wymaga rezygnacji z walki przeciwko krzywdzicielowi. Według Bazylego Wielkiego uciec do innego miasta w czasie prześladowań oznacza: pozostawić Bogu sprawę pomsty, nie stawiać „oporu złemu” (Rz 12, 19), jakby nadstawić drugi policzek (por. Mt 5, 39) ${ }^{46}$. Uciekający pozostawia na przykład swoje mienie, narażając je na konfiskatę. Nie odpłacając złem za złe pozwala, by nieprzyjaciel nadal mógł go krzywdzić. Tymczasem uciekając, wydłuża niejako czas i miejsce działania Bożego. Daje Bogu więcej możliwości, aby wziął w swoje ręce dzieło sprawiedliwości.

7. Posługa apostolska. Orygenes zwraca uwagę na kontekst misyjny przyzwolenia na ucieczkę. W mowie misyjnej Jezusa każde zalecenie jest jakoś związane z głównym nakazem głoszenia królestwa Bożego. Zdaniem Aleksandryjczyka, jeżeli jakiś chrześcijanin ucieka przed prześladowaniami, to postępuje tak nie ze strachu, lecz na polecenie Mistrza; troszczy się o swe ocalenie, ażeby wspomagać innych ${ }^{47}$. Najpierw ucieczka jest usprawiedliwiona unikaniem zgorszenia: „Taki bojaźliwy chrześcijanin niechaj odejdzie z obozu, niechaj wróci do domu, aby innym nie dawał przykładu swego strachu i bojaźni" ${ }^{48}$. Następnie ucieczka tłumaczy się pozytywną racją służby. Pozostający przy życiu człowiek może uczynić wiele dobra innym. Największym dobrem jest wiara, którą da się krzewić pozostając na wolności. W Mt 10, 23a ucieczka nabiera motywu misyjnego. Apostołowie mają przenieść się z wrogiego miasta do innego, aby za ich pośrednictwem Chrystus mógł „przywieść narody do siebie i oświecić światłem poznania"49.

Również i inni autorzy nawiązują do misyjnego motywu ucieczki. Każąc uciekać z miasta do miasta, Jezus - jak thumaczy Cyryl Aleksandryjski - „nie uczy ich lękliwości, ale nie chce, aby narażali się niepotrzebnie na niebezpieczeństwa, bez powodu ginęli i szkodzili tym, którzy mieli odnieść pożytek z ich przepowiadania" 50 . Po ustaniu represji tym znakomitsza chwała stanie się udziałem wiernych, którzy ukryli się przed prześladowcami. Gdy niewiara zostanie potępiona, wielu niewierzących przyjmie łaskę wiary ${ }^{51}$.

Wygnani chrześcijanie budują nowy lud. Apostołowie odłączyli się od Izraela, jak niegdyś Jakub odłączył swój dobytek od dobytku teścia Labana (por. Rdz 30-31). Zmieniając miejsce swego pobytu, wędrując od miasta do miasta, od okolic do okolic, roztropnie unikali gniewu prześladujących ich rodaków.

${ }^{46}$ Por. Basilius Caesariensis, Asceticon magnum II 244, PG 31, 1245, tłum. J. Naumowicz: Św. Bazyli Wielki, Reguły dłuższe, w: Św. Bazyli Wielki, Pisma ascetyczne, t. 2, ŹM 6, Kraków 1995, 384; 244; tenże, Asceticon parvum 158, 2, ed. K. Zelzer, CSEL 86, Vindobonae 1986, 183.

${ }^{47}$ Por. Origenes, Contra Celsum VIII 44, SCh 150, 270, thum. Kalinkowski, s. 407.

${ }^{48}$ Tenże, Homiliae in librum Iudicum IX 1, GCS 30, 519, PSP 34/2, 182.

${ }^{49}$ Tenże, Commentarii in Matthaeum (fragmenta) 71, ed. E. Klostermann - E. Benz, GCS 41/1, Leipzig 1941, 44, tłum. własne.

${ }^{50}$ Cyrillus Alexandrinus, Commentarii in Matthaeum in 10, 23, PG 72, 395C, thum. własne.

${ }^{51}$ Por. Beda Venerabilis, In proverbia Salomonis lib. III in 28, 28, CCL 119B, 138. 
Zwracając się do pogan, dali początek nowemu w wierze ludowi ${ }^{52}$. Niektórzy uważają, że Chrystus w Mt 10, 23a zapowiada swoje nadejście, ostrzegając Żydów i zachęcając do tego, aby się nawrócili. Możliwa jest jednak inna interpretacja, w której przyjścia nie rozumie się w sensie eschatologicznej paruzji, ale Jego obecnego nawiedzenia i troski względem swoich wybranych. Będzie gromadził ich duchowo, gdy rozproszą się pośród różnych ludów i poznają ich języki. Co więcej, zgromadzi całe narody w jedną społecznośćs ${ }^{53}$.

Historyk Orozjusz snuje refleksję nad sensem prześladowań w Hiszpanii w IV w. ze strony plemion germańskich. Jedni chrześcijanie uciekli, inni pozostali. Sytuacja ta doprowadziła do zmieszania się etnicznego ludów. Tak oto chrześcijanie iberyjscy znaleźli się pośród barbarzyńców, takich jak Hunowie, Suewowie, Wandalowie czy Burgundowie. Jeśli nawet ta fuzja wiązała się z pewnym osłabieniem szeregów chrześcijan, to na dłuższą metę miała charakter opatrznościowy, bo stanowiła początek ich chrystianizacji i budowy nowego społeczeństwa ${ }^{54}$.

Motyw apostolski ucieczki staje się tak istotny, że jednemu z komentatorów narzuca duchową interpretację słów Jezusa. Jak Izraelici nieśli Arkę z miasta do miasta, tak głosiciele Słowa przepowiadają je innym. Ponieważ nie rzuca się ,pereł przed świnie” (Mt 7, 6), więc nie należy rzeczy duchowych wyjawić ludziom z góry je odrzucającym (contemptoribus), aby nie zostać ukaranym przez nieroztropność (ex indiscretione). Uciekać z miasta do miasta, to pozostawiać ludzi źle usposobionych, a szukać otwartych na Ewangelię $e^{55}$.

Wspomniany wcześniej przykład Pawła Apostoła uciekającego z Damaszku przed prześladowcami, na który powołuje się Augustyn, ma także swoje uzasadnienie misyjne. Jak zaznacza autor, Paweł uciekł, ale

„modlitwami polecał je Pasterzowi zasiadającemu w niebie, siebie zaś, uciekając, zachował dla ich pożytku, jak to powiedział w innym miejscu: «Pozostać w ciele ze względu, iż jest to konieczne dla was» (Flp 1, 25)"s6.

Na apostolski motyw ucieczki zwraca uwagę Beda Czcigodny, zależny od Augustyna. Św. Paweł wymyka się w Damaszku z zasadzki ludzi nieprawych i udaje się dokąd indziej, gdzie spotyka licznych ludzi gotowych naśladować jego wiarę. Zresztą sam Mistrz uniknął pierwszych represji ze strony Żydów z podobnych powodów. Wobec narastającej nienawiści Żydów Jezus oddalił się ,,W stronę jeziora” (Mk 3, 7). Uniknął ich podstępu, będąc też świadom, że to nie był właściwy czas i miejsce dla Jego Męki. „Odszedł uciekając od złości

${ }^{52}$ Por. Cyrillus Alexandrinus, Glaphyra in Pentateuchum in Genesim IV 2, PG 69, 184.

${ }^{53}$ Por. Procopius Gazaeus, Catena in Esaiam 66, 5-14, PG 87/2, 2717A-B.

${ }^{54}$ Por. Orosius, Historiarum adversum paganos lib. VII 41, 8, PL 31, 1168.

${ }^{55}$ Por. Gregorius Magnus (?), In librum primum Regum expositionum lib. III 85 in 5, 11, ed. P. Verbraken, CCL 144, Turnhout 1963, 245.

${ }^{56}$ Augustinus Hipponensis, In Iohannis evangelium tractatus XLVI 7, ed. R. Willems, CCL 36, Turnhout 1954, 402, tłum. J. Sulowski: Św. Augustyn, Homilie na Ewangelię św. Jana, PSP 15/1, Warszawa 1977, 550. 
swoich prześladowców, a udał się tam, gdzie znalazł wielu gotowych iść za Nim z miłością" 57 . Roztropna troska o własne życia otwiera pewne możliwości misyjne. Taki jej sens wiąże się z samą istotą przesłania mowy misyjnej Jezusa.

Tertulian, z pozycji montanistycznego rygoryzmu, nie pozwala na ucieczkę w czasie prześladowań. Robi jednak wyjątek dla Apostołów, właśnie $\mathrm{z}$ rozpatrywanego względu misyjnego. Twierdzi, że nakaz ucieczki w razie prześladowań:

„dotyczył właściwie apostołów, odnosił się tylko do ich czasów [...]. Od Izraelitów należało rozpocząć dzieło głoszenia ewangelii, najpierw obdzielić chlebem synów, a potem dopiero dawać go psom (por. Mt 15, 26). Dlatego wówczas przez pewien czas Pan polecił im uciekać i to wcale nie po to, by uchronić ich przed prześladowaniem [...]. W nakazie ucieczki chodziło Panu o zapewnienie postępu $\mathrm{w}$ dziele ewangelizacji, aby na skutek prześladowania już na początku nie zabito tych, którzy rozkrzewiają ewangelię. W myśl owego polecenia Pana nie należało także, niejako potajemnie przedzierać się z miasta do miasta, lecz w każdym z nich, pomimo prześladowania otwarcie głosić ewangelię, aż do czasu przepełnienia tego miasta jej nauką. W końcu Pan mówi: «Nie zdążycie obejść wszystkich miast izraelskich» (Mt 10, 23). Wynika z tego, że polecenie ucieczki dotyczyło tylko granic Judei. Nasze zaś przepowiadanie nie ogranicza się tylko do judejskich granic, ponieważ Duch Święty zstąił już na każdego człowieka (por. Dz 2, 17). [...] Jeżeli zaś przestało już ich obowiązywać zastrzeżenie, by nie wstępowali na drogę pogan i do miast Samarii, to dlaczego jednocześnie nie miałoby przestać obowiązywać polecenie ucieczki? Po spełnieniu misji wśród Żydów i przystąpieniu do ewangelizacji pogan, apostołowie nie uciekali już z miasta do miasta i nie uchylali się przed cierpieniem. [...] Skoro więc polecenie ucieczki miało charakter tymczasowy i wydano je samym tylko apostołom, tak było zreszta i z pozostałymi poleceniami ucieczki, nie może odnosić się do nas polecenie, które przestało obowiązywać naszych nauczycieli”"58.

Zauważamy u Tertuliana aprioryczność w odrzucaniu ucieczki chrześcijan przed represjami. W okresie przedmontanistycznym przyzwalał na taką ucieczkę: ,jeśli trzeba uciekać, ciało pokonuje przykrości ucieczki”59. W interpretacji Kartagińczyka ta sama racja apostolskiego działania każe Apostołom raz uciekać przed prześladowaniami, a innym razem nie: unikać ich, gdy nawracają Żydów, a nie unikać, gdy nawracają pogan.

Podobnie jak Tertulian, także Hieronim w komentarzu do Mt 10, 23a wychodzi od kontekstu ścisłego tych słów. Zalecenie w sensie historycznym

${ }^{57}$ Beda Venerabilis, In Marci evangelium expositio I in 3, 7, ed. D. Hurst, CCL 120, 466, thum. własne.

${ }^{58}$ Tertullianus, De fuga in persecutione 6, CCL 2, 1142-1143, PSP 65, 162.

${ }^{59}$ Tenże, De patientia XIII 6, ed. J.G. Borleffs, CCL 1, 314, tłum. E. Stanula: Tertulian, O cierpliwości, w: Tertulian, Wybór pism, PSP 5, Warszawa 1970, 171. 
odnosi się do pierwszej misyjnej posługi Apostołów, mianowicie wśród swoich rodaków:

„Należy to odnieść do owego czasu, gdy apostołowie byli wysyłani na głoszenie [nauki], którym też szczególnie powiedziano: «Nie idźcie do pogan i nie wstępujcie do miast Samarytan» (Mt 10, 5). Według Jezusa nie powinni oni bać się represji ze strony Żydów, a w razie czego zmieniać miejsce swego pobytu".

Hieronim dokonuje przeskoku i zaraz przechodzi do innego momentu posługi apostolskiej, do przepowiadania Ewangelii po śmierci i zmartwychwstaniu Chrystusa:

„To właśnie widzimy, że na początku uczynili wierzący, kiedy po rozpoczęciu prześladowań w Jerozolimie rozproszyli się po całej Judei, tak że ucisk stał się zasiewem Ewangelii" ${ }^{\prime 0}$.

W tym momencie Hieronim, podobnie jak Tertulian, nie rozciaga waloru misyjnego ucieczki na czasy przyszłe. Pochwała za roztropność, jakiej udziela prorokowi uciekającemu przed prześladującym go królem Jojakimem ${ }^{61}$, pozwala przypuszczać, że Hieronim, pewnie zależny w interpretacji Mt 10, 23a od Tertuliana, nie poszedł tak daleko jak poprzednik, by zalecenie ucieczki ograniczać jedynie do działalności Apostołów w Judei. Tymczasem będzie zataczać szerokie kręgi powyższa myśl Hieronimowa: „tribulationis occasio fieret Evangelii seminarium" ${ }^{2}$.

Rozpatrując słowa Jezusa w Mt 10, 23a, Augustyn usiłuje je przełożyć na konkretną postawę duszpasterską. Zajęty ochroną aktualnych zdobyczy Kościoła, prześladowania postrzega nie tyle pod kątem misyjnym, co duszpasterskim. Afryka Północna stoi w obliczu najazdu Wandalów. Biskup Hippony myśli nie tyle, co da ucieczka, ale pozostanie na miejscu. Kiedy z kolei duszpasterz może zbiec z miejsca swojej posługi? W 429 r. biskup Thiabe, Honoriusz, zapytał go, jak mają postępować pasterze w sytuacji zagrożenia ich kościołów. Biskup Hippony zaleca wiernie trwać na swoim urzędzie. Czy narażanie swego życia nie stoi w sprzeczności ze słowami Jezusa w Mt 10, 23a? Augustyn udziela listownie obszernej odpowiedzi. Zamieszczając list w całej rozciagłości w biografii Augustyna, Possydiusz pewnie uznał to pismo za szczególnie cenne dziełko mistrza ${ }^{63}$.

Biskup Hippony stwierdza, że, owszem, zachodzi nieraz potrzeba ucieczki, ale pod warunkiem, że nie utraci się większego dobra. Jezus został zabrany

\footnotetext{
${ }^{60}$ Hieronymus, Commentarii in evangelium Matthaei I in 10, 23, CCL 77, 69, ŹMT 46, 57.

${ }^{61}$ Por. tenże, In Hieremiam prophetam lib. V in 26, 20, CSEL 59, 330.

${ }^{62}$ Por. np. Beda Venerabilis, Expositio actuum apostolorum in 8, 1, ed. M.L. Laistner, CCL 121, Turnhout 1983, 39.

${ }^{63}$ Por. Possidius, Vita Augustini 30, PL 32, 60-62, tłum. P. Nehring: Possydiusz z Kalamy, Żywot św. Augustyna, ŹM 26, Kraków 2002, 111-126.
} 
jako niemowlę do Egiptu, ale nie porzucił wtedy żadnych Kościołów, ponieważ jeszcze ich nie założył. Paweł Apostoł ratował się ucieczką z Damaszku, ale Kościół w tym mieście nie został pozbawiony pasterzy, bo byli tam inni bracia, a to jego właśnie szukał prześladowca. Dzięki temu Paweł został zachowany dla całego Kościoła ${ }^{64}$. Tak postąpił też Atanazy Aleksandryjski, który opuścił Aleksandrię prześladowany przez Konstancjusza, podczas gdy inni duchowni mogli sprawować pieczę nad jego wiernymi ${ }^{65}$. Augustyn formułuje następującą zasadę dla szafarzy słowa i sakramentów:

„niech uciekają z miasta do miasta wtedy, gdy prześladowcy szczególnie domagają się któregoś z nich, ale tak, żeby Kościół nie został pozbawiony innych, którzy nie są w ten sposób poszukiwani, aby oni dostarczali pokarmów swoim współsługom, o których wiedzą, że inaczej nie mogą żyć. Gdy zaś wspólne niebezpieczeństwo zagraża wszystkim, to jest biskupom, duchownym i świeckim, to niech ci, którzy potrzebują innych, nie zostaną opuszczeni przez tych, których potrzebują. Zatem niech wszyscy razem przeniosą się w bezpieczne miejsca, albo niech ci, którzy koniecznie muszą pozostać, nie będą opuszczeni przez tych, za sprawą których ma być zaspakajana ich kościelna potrzeba, żeby albo jednakowo żyli, albo jednakowo ścierpieli to, co Ojciec rodziny zechciał, ażeby mężnie znieśli" ${ }^{\prime 66}$.

Pozostanie na miejscu zagrożenia ze względu na dobro innych jest wielkim świadectwem miłości ${ }^{67}$, zwłaszcza że, jak dalej podkreśla Augustyn, ludzie bez posługi szafarzy „nie mogą ani stać się chrześcijanami, ani żyć jak chrześcijanie" ${ }^{68}$. W Mt 10, 23a Jezus dozwala, a nawet nakazuje ucieczkę, a innym razem ją odrzuca, ukazując obraz dobrego pasterza, który nie porzuca owiec podczas napaści wilka (por. J 10, 12. 18). Obie wypowiedzi Jezusa są prawdziwe, tylko należy je właściwie rozumieć i godzić ze sobą, co nie jest rzeczą trudna, jeśli uwzględnimy powyższe racje ${ }^{69}$. Tak więc motyw duszpasterski ma charakter względny: może kazać uciec przed represjami lub pozostać.

8. Dobro prześladowcy. „Wyobraźnia miłosierdzia” każe myśleć podczas ucieczki nie tylko o dobru opuszczanych wiernych, nieraz także narażonych na prześladowania, ale również o dobru prześladowców. Do racji tej Ojcowie odwołują się często, tak że odnosimy wrażenie, iż nie należała ona do ubocznej motywacji.

${ }^{64}$ Por. Augustinus Hipponensis, Epistula 228, 2, PL 57, 485.

${ }^{65}$ Por. tamże 228, 6, PL 57, 488.

${ }^{66}$ Tamże 228, 2, PL 57, 485-486, thum. P. Nehring: Possydiusz z Kalamy, Żywot św. Augustyna, ŹM 26, Kraków 2002, 113.

${ }^{67}$ Por. tamże 228, 3, PL 57, 486, ŹM 26, 115.

${ }^{68}$ Tamże 228, 4, PL 57, 487, ŹM 26, 115.

${ }^{69}$ Por. tamże 228, 6, PL 57, 488. 
Klemens Aleksandryjski nie neguje wartości męczeństwa i zaleca gotowość na wszystko ${ }^{70}$, jednak sytuacja nie zawsze domaga się świadectwa krwi. W Ewangelii Mateusza 10, 23 Jezus:

„bynajmniej nie zachęca do ucieczki, jak gdyby znoszenie prześladowania miało być jakimś złem, ani nie poleca nam uchylać się przed śmiercią poprzez ucieczkę, jak gdybyśmy doznawali obawy przed śmiercią, lecz pragnie, abyśmy nigdy w stosunku do nikogo nie stali się winnymi ani współwinnymi jakiegokolwiek zła: ani w stosunku do siebie samych, ani w stosunku do naszego prześladowcy czy tego, który nas chce zgładzić; oto podaje nam pewien sposób, aby zejść mu z drogi. Kto natomiast puści przestrogę mimo uszu, ten jest nadmiernie zuchwały i awanturniczo lekkomyślny"’1.

Uniknięcie represji może służyć dobru uciekiniera, gdyż zapobiega apostazji człowieka nieczującego się na siłach, by stawić czoła prześladowcy. Może też obrócić się w pożytek prześladowcy, gdyż nie zostaje on sprowokowany do wrogich czynów.

Rzecz ujmuje pozytywniej Piotr Chryzolog. Prawdziwy świadek Chrystusa, pochwycony przez prześladowcę, zachowuje stałość, gotowy ponieść śmierć męczeńską; jeśli natomiast nie zostaje pochwycony, powinien uciekać przed prześladowca. Czyni tak nie tylko ze względu na własne dobro, zapewniając sobie czas na modlitwę i błaganie do Boga, ale także ze względu na dobro prześladowcy, któremu tym samym daje czas do namysłu. Prowokując przeciwnika czyni go prześladowca, unikając go daje mu okazję do poprawy ${ }^{72}$. Unikając represji nie tylko unika się pewnego zła, ale stwarza się szansę na dobro: własną przemianę wewnętrzną oraz nawrócenie prześladowcy.

Chrystus nie chce, aby prześladowani chrześcijanie, pozostając z uporem w jednym miejscu, stali się w jakiś sposób sprzymierzeńcami diabła. Daliby mu broń do ręki przez to, że swoim prześladowcom dostarczyliby okazji do zabijania, czyniąc ich jeszcze bardziej bezwzględnymi. Wprost przeciwnie, mają czuwać i modlić się, aby nie byli wystawieni na pokuszenie. Jeśli Apostołowie narażali się na śmierć, to z powodu wyższej konieczności, ze względu na braci. Gdyby ktoś jednak sam od siebie to czynił nie powodowany żadną koniecznością, może rozminąć się z wolą Bożą i dobrem bliźniego ${ }^{73}$.

Na kartach Biblii i w dziejach odnajdujemy przykłady liczenia się z dobrem nieprzyjaciół. Według Hieronima taki przykład dał Chrystus. Na wieść

${ }^{70}$ Por. H. Ostrowski, Wiara a męczeństwo w „Dywanach” Klemensa Aleksandryjskiego, VoxP

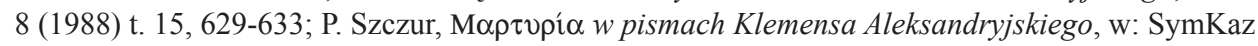
4, 2004, 103-105.

${ }^{71}$ Clemens Alexandrinus, Stromata IV 76, 1, ed. O. Stählin - L. Früchtel, GCS 52, Berlin $1960^{3}$, 282, thum. J. Niemirska-Pliszczyńska: Klemens Aleksandryjski, Kobierce zapisków filozoficznych dotyczacych prawdziwej wiedzy, t. 1, Warszawa 1994, 338-339.

${ }_{72}$ Por. Petrus Chrysologus, Collectio sermonum 151, 6, CCL 24B, 945.

${ }^{73}$ Por. Petrus Alexandrinus, Epistula canonica 9, ed. M.J. Routh, Reliquiae sacrae, t. 4, Oxonii $1846^{2}, 33$. 
o śmierci Jana Chrzciciela oddalił się na odosobnienie (por. Mt 14, 13). „Nie, jak przypuszczają niektórzy, z obawy przed śmiercią, lecz przez wzgląd na nieprzyjaciół swoich, aby nie dodawali kolejnego zabójstwa"74. Istnieje obawa, że pozostaniem na miejscu będzie się prowokować prześladowcę, a sobie gotować upadek. Takiej prowokacji unikał Dawid, który ukrywając się przed prześladującym go synem Absalomem zdobywał sympatię ludności i jej gościnność. Żeby jednak nie narażać innych na podobne niebezpieczeństwo, szukał schronienia w miejscach odosobnionych (por. 2Sm 15-16) ${ }^{75}$. Podobnie pierwsi chrześcijanie kryli się przed prześladujących ich Szawłem. Zachowani przy życiu, mogli w przyszłości stać się jego nauczycielami: „Gdyby męczennicy nie unikali Szawła, nie uczyniliby Pawła męczennikiem"”76. W końcu ponieśli też śmierć męczeńską.

Za panowania Konstantyna działał Marek z Aretuzy, który niszczył świątynie pogańskie i nawracał na chrześcijaństwo. Gdy sytuacja obróciła się na niekorzyść chrześcijan, stał się przedmiotem pogańskiego ataku.

„Widząc więc poruszenie thumu przeciwko sobie, [...] najpierw pragnie uciekać, nie z tchórzostwa, ile raczej wykonując rozkaz, by uciekać z gminy do gminy i ustępować przed prześladowcami. Chrześcijanie bowiem powinni zważać nie tylko na swoje sprawy, [...] ale i prześladowców swoich oszczędzać, aby na ile to od nich zależy, nie przyczynili się w czym do tym większego potępienia nieprzyjaciół" "ᄁ7.

W końcu jednak widząc, jak jedni narażają się ukrywając go, a drudzy tracą ducha w obliczu represji, postanowił wrócić z ucieczki.

Atanazy Wielki usprawiedliwia przed cesarzem Konstancjuszem swoją decyzję opuszczenia stolicy biskupiej w Aleksandrii, podczas gdy władze popierające arianizm zesłały biskupów z Libii i Tebaidy w odległe i bezludne miejsca:

„I nie dlatego uciekłem, żebym się bał śmierci. Nikt z nich nie może mnie posądzić o tchórzostwo. Jest jednak nakaz Zbawiciela, żebyśmy uciekali, gdy nas ścigają byśmy nie narażali się na niebezpieczeństwa, które przewidujemy, zwłaszcza że zbytnim pokazywaniem się można łatwo rozbudzić nienawiść ścigających. Bo wydać się wrogom na śmierć to tyle samo, co popełnić samobójstwo, ucieczka natomiast nakazana przez Zbawiciela równa jest rozpoznaniu odpowiedniej chwili i trosce o prześladujących, żeby dążeniem do rozlewu krwi nie przekroczyli przykazania «Nie zabijaj!». A oskarżyciele moi tego właśnie najbardziej pragną"

${ }^{74}$ Hieronymus, Commentarii in evangelium Matthaei II in 14, 13, CCL 77, 119, ŹMT 46, 95.

${ }^{75}$ Por. Eusebius Caesariensis, Commentarii in Psalmos 56, 2, PG 23, 505.

${ }^{76}$ Petrus Chrysologus, Collectio sermonum 151, 6, CCL 24B, 946, tłum. własne.

${ }^{77}$ Gregorius Nazianzenus, Oratio IV 88, ed. J. Bernardi, SCh 309, Paris 1983, 222, thum. zbiorowe: Święty Grzegorz z Nazjanzu, Mowy wybrane, Warszawa 1967, 96.

${ }^{78}$ Athanasius Alexandrinus, Apologia ad Constantium 32, ed. J.M. Szymusiak, SCh 56bis, Paris 
Obecność w czasie represji może prowokować prześladowców, jest działaniem przeciwko samemu sobie, a na korzyść wrogów, a ostatecznie na niekorzyść, bo prowadzi do ich zbrodniczego postępowania.

9. Świadectwo wyrzeczenia. Nasi autorzy są przekonani, że ucieczka przed prześladowcami może być pewnym rodzajem świadectwa wiary, analogicznym do męczeństwa. Uciekinier płaci cenę za czyn podjęty dla ochrony swojej wiary, którą na swój sposób wyznaje. Powiada Orygenes: „Kto ucieka, aby się nie wyrzec, w jakiś sposób Go właśnie wyznaje"

Uciekający chrześcijanie są narażeni na wiele przykrości, jak głód, pragnienie czy zimno. O ich poniewierce pisał już autor Listu do Hebrajczyków: ,tułali się w skórach owczych, kozich, w nędzy, w utrapieniu, w ucisku, [...] błąkali się po pustyniach i górach, po jaskiniach i rozpadlinach ziemi” (Hbr 11,38). To wszystko jest już stanem prześladowania, i to bardzo wielkiego (maxima tribulatio) $^{80}$. Uciekając przed represjami, św. Berenika i Prosdokia nie tylko nie zasłużyły na naganę, ale nawet otrzymały wieniec razem z innymi. Uciekając wyrzekły się bliskich, majątku ojczyzny i wszystkiego, aby posiąść życie wieczne (por. Mt 19, 29) ${ }^{81}$.

Exodus na pustynię, stojący u początków potężnego ruchu monastycznego w IV w., nastąpił z motywów ascetycznych. Na takie motywy wskazuje literatura monastyczna, opisująca wyjście na pustyni pionierów tego rodzaju życia. Wyrzeczenie się rodziny, majętności, walka z namiętnościami stanie się treścią ascezy monastycznej zwanej „białym męczeństwem”. Początki tego zjawiska objęte są mrokiem historii i wydaje się bardzo prawdopodobne pierwotne nakładanie się tych dwóch motywów anachorezy: zachowania życia dzięki ucieczce i wyrzeczenia się go przez ascezę. Pustynna asceza mogła być nieraz konsekwencją ucieczki przed prześladowaniami, ale też i naśladowania przez wyrzeczenie Mistrza. Znamienne, że pustelnicy nazwali swoją anachorezę tym samym słowem ỏv $\alpha \chi \omega \rho \varepsilon \hat{v} v$, którym Ewangeliści nazywali oddalenie się Jezusa od ludzi (np. Mt 12, 15).

Beda opowiada żywot św. Feliksa z Noli, wyznawcy, bliskiego współpracownika świątobliwego biskupa Maksyma. Wobec groźby tortur, na które prześladowcy chcieli zaprowadzić Maksyma, biskup uciekł w góry, posłuszny

1987, 164, tłum. J. Ożóg, w: Św. Atanazy, Apologie, PSP 21, Warszawa 1979, 186. Tę apologię ucieczki streszcza Sokrates Scholastyk, HE III 8, PG 67, 396-404, Kazikowski, s. 288-292.

${ }^{79}$ Origenes, Homiliae in librum Iudicum IX 1, GCS 30, 519, PSP 34/2, 182.

${ }^{80}$ Por. Ambrosius Autpertus, Expositio in Apocalypsin IV in 7, 13, CCM 27, 318.

${ }^{81}$ Por. Joannes Chrysostomus, De sanctis Bernice et Prosdoce 5, PG 50, 636. Te antiocheńskie chrześcijanki żyjące w czasach Dioklecjana, w obawie przed zhańbieniem przez żołnierzy, rzuciły się do pobliskiej rzeki i potonęły. Idąc za innymi autorami, Augustyn (De civitate Dei I 26, ed. B. Dombart-A. Kalb, CCL 47, Turnhout 1955, 26-27, tłum. W. Kubicki: Św. Augustyn, Państwo Boże, Kęty 1998, 51) tłumaczy ich postawę posłuszeństwem natchnieniu Bożemu, lecz przestrzega przed niewolniczym ich naśladowaniem. Jeśli Kościół czci je jako męczenniczki, to może na podstawie jakiegoś wiarygodnego objawienia Bożego. 
zaleceniu Jezusa, pozostawiając w Noli swego prezbitera. Tymczasem prześladowcy skierowali swoją złość przeciwko zastępcy biskupa, torturowali go i zamknęli do więzienia. Biskup w tym czasie cierpiał głód i zimno w swojej górskiej kryjówce. Anioł z nieba zlitował się i sprowadził Feliksa z więzienia do swego biskupa, aby go pokrzepić. Po śmierci Maksyma Feliks został wybrany przez lud na jego następcę, ale nie przyjął godności biskupiej. Umarł jako wyznawca ${ }^{82}$.

Przeciwko tak zwanym joannitom, to jest duchownym nieuznającym depozycji Jana Chryzostoma, podjęto represje. Nowy biskup Konstantynopola, Attikus, wydał dekrety nakazujące wydalenie z Kościoła i konfiskatę mienia tych biskupów, którzy nie uznawali hierarchii kościelnej odpowiedzialnej za złożenie Złotoustego z urzędu. Niektórzy podporządkowali się rozporządzeniom, ale inni z kolei, nie zważając na ,pochodzenie, majątek, ojczyznę, przemijającą chwałę czy fizyczne cierpienie", zachowali czyste sumienie. Zgodnie z radą Jezusa uratowali się ucieczką: jedni uciekli do Rzymu, drudzy w góry, inni na pustkowie ${ }^{83}$.

Przykazanie Pana nakazujące ucieczkę dotyczy także tych, którzy przyjmują uciekających. Mają nie tylko ich ugościć, ale i podtrzymać na duchu oraz okazać swoją solidarność. W Konstytucjach Apostolskich znajdujemy taki apel:

„Przyjmujcie tych, którzy są prześladowani za wiarę i zgodnie z poleceniem Pana z jednego miasta uciekają do innego; pomagajcie im, troszczcie się o nich i przyjmujcie ich jako męczenników, cieszcie się, że możecie razem z nimi znosić prześladowania, wiedząc, że Pan uznał ich za błogosławionych" ${ }^{\prime 4}$.

Gościnność i szacunek okazane prześladowanym są chwalebnym udziałem w ich cierpieniu, a więc i jakimś świadectwem wiary.

10. Sens duchowy. Rozwinięta w starożytności szkoła alegorycznej egzegezy nie pominęła również i rozpatrywanego logionu. W odniesieniu między innym do Mt 10, 23a Hieronim wskazuje na dwie możliwe interpretacje:

„Inne miejsca w Piśmie Świętym można łatwo, a nawet trzeba, thumaczyć, zarówno historycznie (dosłownie), jak i alegorycznie (w przenośni), obydwa bowiem thumaczenia dostarczają duszy życiodajnych soków"85.

${ }^{82}$ Por. Beda Venerabilis, Vita sancti Felicis, PL 94, 789-790.

${ }^{83}$ Palladius, Dialogus de vita Joannis Chrysostomi 11, ed. P.R. Coleman-Norton, Cambridge 1928, 65, thum. własne.

${ }^{84}$ Constitutiones Apostolorum V 3, 1, ŹMT 42 [tekst grecko-polski, opr. A. Baron - H. Pietras, thum. S. Kalinkowski], Kraków $2007=$ SCL 2, 108. To samo w: Didascalia Apostolorum V 3, 1, ed. F.X. Funk, Didascalia Apostolorum et Constitutiones Apostolorum, t. 1, Padernbornae 1905, 241.

${ }^{85}$ Joannes Cassianus, Collationes Patrum XXIV 8, 3, ed. M. Petschenig, CSEL 13, Vindobonae 1886, 220, thum. A. Nocoń, w: Jan Kasjan, Rozmowy z Ojcami, t. I. Rozmowy I-X, ŹM 28, Kraków $2002,335$. 
Pojawia się pytanie, czy duchowe rozumienie słów Jezusa nie wskazuje jakiejś innej ucieczki dozwolonej chrześcijaninowi i nie odnajduje dla niej swoich racji. Zanim odpowiemy na pytanie, postaramy się przedstawić wszystkie dostępne nam interpretacje alegoryczne Mt 10, 23a. Jedną z nich ukazaliśmy już wcześniej ${ }^{86}$.

W świetle przenośnie rozumianych słów z Mt 10, 23a Orygenes formułuje egzegetyczną zasadę: Scriptura ex Scriptura explicanda est. Jeśli w sporze o rozumienie Pisma Świętego nasi oponenci - sofiści czy jacyś inni dyskutanci skłonni do sporów - uchwycą się jednego fragmentu, należy „uciekać do innego miasta", to jest szukać wyjaśnienia prawdy za pomocą innych podobnych miejsc biblijnych, by po zbadaniu wszystkich wyjaśnić zagadnienie. Nie zdołamy przejść wszystkich takich miejsc, a Syn Człowieczy oświeci nas promieniami swojej prawdy. Aleksandryjczyk dostrzega jeszcze inne alegoryczne znaczenie „miast Izraela”. Oznaczają one heretyków lub ludzi nieprawych ${ }^{87}$. Choć Apostołowie nie zdołają ich pozyskać ze względu na brak w nich dobrej woli, to jednak sami odniosą pożytek ze zgłębianego i przepowiadanego Słowa. Do alegorycznej interpretacji Orygenesa odwołuje się Hieronim:

„Na sposób zaś duchowy możemy powiedzieć: gdy was prześladować będą w jednym mieście, to jest w oparciu o jedną księgę Pism czy jeden cytat, my uciekajmy do innych miast, to jest do innych ksiag. Choćby był wojowniczy prześladowca, wcześniej nadejdzie pomoc Zbawiciela niż przeciwnikom będzie dane zwycięstwo" $"$.

Starcia z błędnymi interpretatorami Pisma Świętego, jednostronnie trzymającymi się jednego świadectwa biblijnego, każą szukać wsparcia w całej Biblii. Chociaż Hieronim zwalcza miejscami alegoryzm Orygenesa, często go jednak naśladuje. Sens duchowy pociaga jego umysł.

Wyjaśniając alegorycznie Mt 10, 23a Ambroży odwołuje się do Pnp 2, 17 (LXX): „Uciekaj, bracie mój, i bądź podobny do gazeli lub do młodego jelenia na górach". Gdy Kościół-Oblubienica jest prześladowany ze względu na Chrystusa, Oblubieniec „ucieka w góry”. To znaczy wobec słabości tych, którzy nie są w stanie znieść cięższej próby, w jakiś sposób oddala się od nich, a odwołuje się do swoich świętych, gotowych na męczeństwo, i na nich opiera zagrożony Kościół ${ }^{89}$. Ucieczka „,z jednego miasta do drugiego" to pewien zwrot Chrystusa od swoich członków słabszych do mocniejszych.

Jak już wcześniej wskazaliśmy, Augustyn aplikuje Mt 10, 23a, w dosłownym sensie tych słów, do pasterzy, którym wolno uciec przed represjami

\footnotetext{
${ }^{86}$ Por. Gregorius Magnus (?), In librum primum Regum expositionum lib. III 85, CCL 144, 245.

${ }^{87}$ Por. Origenes (?), Fragmenta e catenis in Psalmos in Ps 137, 20, ed. J.B. Pitra, Analecta sacra, t. 3, Venetiis 1883, 345-346.

${ }^{88}$ Hieronymus, Commentarii in evangelium Matthaei I in 10, 23, CCL 77, 70, ŹMT 46, 57.

${ }^{89}$ Por. Ambrosius Mediolanensis, Expositio psalmi CXVIII 22, 43, ed. M. Petschenig, CSEL 62, Vindobonae 1913, 509.
} 
jedynie wtedy, gdy ucieczka nie zaszkodzi dobru ich wiernych. Autor dostrzega również duchowy wymiar ucieczki. Z powodu takiej „ucieczki” należy się pasterzowi nagana. Otóż pasterz odchodząc od owczarni źle postępuje wtedy, gdy „siebie samego szuka, a nie tego, co jest Jezusa Chrystusa; nie odważa się grzesznika otwarcie upominać" ${ }^{0}$. Przenośną ucieczką jest unikanie odpowiedzialności pasterskiej, jak na przykład trudnego karcenia, upominania. Idąc po linii interpretacji alegorycznej Augustyna, wolno więc zapytać, jaka ucieczka pasterza „z jednego miasta do drugiego” pasterza jest dobra. Odpowiedź narzuca się sama. Dobrą ucieczką jest zmiana odpowiedzialności, rodzaju troski pasterskiej, jeśli zachodzi potrzeba. Temat złej „ucieczki” w powyższym alegorycznym sensie nazywa Augustyn zagadnieniem „trudnym"91, jednak, jak widzimy, go nie unika.

Gdzie indziej biskup Hippony uznaje za duchową ucieczką, dozwoloną przez Jezusa w Mt 10, 23a, odejście ciała z duszy na skutek śmierci męczeńskiej. Ktoś może zostać tak pochwycony, że nie ma możliwości fizycznej ucieczki. Ciało „ucieka”, ale duch pozostaje przez mężne stawienie czoła prześladowcy i wyznanie wiary ${ }^{92}$. Ostatecznie męczennik odzyska także i ciało. Stwórca odtworzy je „w lepszym stanie niż było"93. Odwołując się do duchowej interpretacji, Augustyn stara się pokazać aktualność słowa Bożego w sytuacji, gdy nie da się je praktykować w sensie dosłownym. Tymczasem obca pozostaje chrześcijaninowi ucieczka $\mathrm{z}$ ciała $\mathrm{w}$ sensie samobójstwa. $\mathrm{W}$ aluzji do Mt 10, 23a Augustyn występuje przeciwko poglądom akceptującym samobójstwo. Pod wpływem lektury Platona filozof akademicki, Kleombrot z Ambracji, zabił się rzucając się $\mathrm{z}$ murów miasta w morze. Nawet zagrożonym przez prześladowców wyznawcom Chrystus zabrania takiego uczynku, dając możliwość ucieczki ${ }^{94}$.

Wyżej przedstawione wykładnie naszych komentatorów Mt 10, 23a są spekulacją nad Słowem Bożym o charakterze zdawkowym i ubocznym, służącą okazyjnie do poparcia jakiejś tezy. Nie wniosły czegoś istotnego w egzegezę słów Jezusa czy praktykę życia chrześcijańskiego, a jedynie rozszerzyły perspektywę dla egzystencjalnej, duchowej lektury Słowa Bożego. Istnieje jednak jeszcze inny, metaforyczny sens zalecenia Jezusa, który mógł odegrać większą rolę w świadomości chrześcijan. Kiedy minęła epoka prześladowań, chrześcijanie pytali, co dla nich teraz oznacza zachęta Jezusa do ucieczki. Ktoś zapytał starca z Gazy: „«Dlaczego więc napisano: 'Gdy was wyrzucać będą z tego

${ }^{90}$ Augustinus Hipponensis, In Iohannis evangelium tractatus XLVI 8, CCL 36, 402-403, PSP $15 / 1,550$.

${ }^{91}$ Tamże.

${ }^{92}$ Por. tenże, Enarrationes in Ps. 141, 11, ed. E. Dekkers - J. Fraipont, CCL 40, Turnhout 1956, 2053-2054, tłum. J. Sulowski: Augustyn z Hippony, Objaśnienia Psalmów, PSP 42/1, Warszawa 1986, 243; Verecundus Iuncensis, Commentarii super cantica ecclesiastica. In canticum Hieremiae 5, ed. R. Demeulenaere, CCL 93, Turnhout 1976, 71.

${ }^{93}$ Augustinus Hipponensis, Enarrationes in Ps.139, 16, CCL 40, 2024, PSP 42/1, 210.

${ }^{94}$ Por. tenże, De civitate Dei I 22, CCL 47, 23-24, thum. Kubicki, s. 47. 
miasta, uciekajcie do innego'?» On zaś powiedział: «Ale nas nie wyrzucają»"95. Nie godząc się na spekulację nad radą Jezusa, starzec-rekluz zdawał się milcząco wskazywać na możliwy inny rodzaj ucieczki, który sam praktykował.

U Orygenesa spotykamy wyjaśnienie Mt 10,23a, które mogło mieć duże znaczenie dla przyszłej wykładni tych słów. Być może dłuższy czas pokoju, którym cieszył się Kościół za życia Aleksandryjczyka, przerwany dopiero pod jego koniec, kazał szukać szerszego sensu rady Jezusowej, poza kontekstem prześladowań. Ucieczkę chrześcijanina łączy z uczynkiem Jozuego, będącego figurą Jezusa, który uciekł ze względów taktycznych przed wojskiem miasta $\mathrm{Aj}$ (por. Joz 8, 15). Uciec przed wrogami to uciec przed złem - rozpusta, gniewem, chciwością, zawiścią, zazdrością obmową czy oszczerstwem:

„Chce więc [Jezus], abyśmy uciekali przed takimi wrogami [...]. A jeśli zdołamy kiedyś dzięki ucieczce uniknąć zetknięcia się z tym złem, wówczas wszystkie święte potęgi [...], widząc naszą pobożność i nastawienie naszego umysłu, $[\ldots]$ że doznajemy napaści ze strony demonów, powstaną przeciwko naszym prześladowcom i uderzeniem od tyłu zabiją ich wszystkich. Jezus bowiem jest raczej z tymi, którzy cierpią prześladowanie, aniżeli z tymi, którzy atakują. I słusznie, bo Jezus znajduje radość w przebywaniu z tymi, którzy uciekają przed rozpusta, przed pycha, podstępem i kłamstwem"96.

Poza prześladowcami zewnętrznymi, są prześladowcy wewnętrzni, przed których tyranią godzi się uciekać: zło oraz złe duchy. Najbezpieczniejsza jest ucieczka uprzedzająca wrogi atak. Taki rodzaj ucieczki wspiera sam Zbawiciel.

$\mathrm{Na}$ tę duchową ucieczkę wskazuje również Ambroży, pilny czytelnik pism Orygenesa:

„Albowiem choć z powodu słabości ciała (Pan) zdaje się nam doradzać ucieczkę, jednakże lepiej ucieka ten, kto ucieka przed ponętą światową, aby go nie zatrzymywała troska o nabycie bogactw, przypatrywanie się swym skarbom, pożądanie dóbr tego życia"97.

Autor nie wyjaśnia, dlaczego taka ucieczka jest lepsza. Z kontekstu wynika, że ten ascetyczny rodzaj ucieczki ma na celu uniknięcie grzechu. Ucieczka przed prześladowaniami jest ucieczką przed pewnymi zewnętrznymi okolicznościami i nie zawsze zachodzi jej potrzeba. Tymczasem przed grzechem chrześcijanin zawsze ucieka, ponieważ grzech jest zawsze czymś złym. Zdaniem

${ }^{95}$ Barsanuphius et Joannes, Quaestiones et responsiones ad laicos et episcopos 787, ed. P. Neyt - P. de Angelis-Noah - L. Regnault, SCh 468, Paris 2002, 244, tłum. E. Dąbrowska: Barsanufiusz i Jan, Listy, ŹM 69, Kraków 2014, 917.

${ }^{96}$ Origenes, In Iesu Nave hom. VIII 6, ed. W.A Baehrens, GCS 30, Leipzig 1921, 341, thum. S. Kalinkowski: Orygenes, Homilie o Księdze Jozuego, w: Orygenes, Homilie o Księgach Liczb, Jozuego, Sędziów, PSP 34/2, Warszawa 1986, 49.

${ }^{97}$ Ambrosius Mediolanensis, De fuga saeculi 4, 17, ed. C. Schenkl, CSEL 32/2, Vindobonae 1897, 179, tłum. W. Szołdrski: Św. Ambroży, O ucieczce od świata, w: Św. Ambroży, Wybór pism, PSP 7, Warszawa 1971, 102. 
Augustyna, jeśli Pan nakazał swym uczniom uciekać przed prześladowaniami, które mogą przecież przynieść obfity owoc męczeństwa, to tym bardziej należy uciekać przed ,jałowymi cierpieniami” (steriles passiones) ${ }^{98}$.

W IV w. zrodzi się ruch monastyczny, który w założeniu będzie miał pewną ucieczkę od świata. Mnich udaje się na odosobnienie, aby odsunąć się od „ponęty światowej”. Gdy Orygenes i Ambroży odnajdują w Mt 10, 23a zachętę do ucieczki duchowej, to pierwszy jest jakby prekursorem tego zjawiska, a drugi - jego naocznym świadkiem i rzecznikiem. Tak oto ta Ewangelia inspiruje w różnych okolicznościach życia, zarówno w pomyślności, jak i utrapieniu.

11. Przykład św. Cypriana. Zatrzymując się nad różnymi racjami unikania represji, wskazywaliśmy za Ojcami na przykład Chrystusa oraz świętych - Pawła Apostoła, Atanazego Aleksandryjskiego, Dionizego Wielkiego, Jana Jałmużnika, męczenników: Kwiryna, Agapy, Ireny, Chionii, Genezjusza, wyznawców: Bereniki, Prosdokii, Feliksa z Noli, Maksyma. Na zakończenie wspomnimy o postawie Cypriana z Kartaginy podczas prześladowań i jego uzasadnieniu ucieczki. Biskup dwukrotnie zdecydował się na ukrycie przed represjami: w 250 r. podczas prześladowań za cesarza Decjusza oraz w $258 \mathrm{r}$. za Waleriana. W końcu zginął jako męczennik 14 września 258 r. Kilkakrotnie wyjaśnia sens własnej decyzji. Poświęca osobny list tej kwestii. Jego biograf, Poncjusz, dokonuje obszernej apologii postawy biskupa ${ }^{99}$.

$\mathrm{W}$ liście ósmym w zbiorze zachowanej korespondencji autor thumaczy posłuszeństwem Chrystusowi swoje pierwsze odejście z zagrożonej siedziby biskupiej: ,Zgodnie z przykazaniem Pana usunąłem się tymczasowo"100. Przez mandata Domini ma na myśli pewnie zalecenie Jezusa w Mt 10, 23a. Tę motywację przypisuje Cyprianowi jego biograf:

„Istotnie zachodziła słusznie obawa, że raczej należało spełnić wolę Bożą, niż przed czasem otrzymać koronę męczeńską. Dusza bowiem, we wszystkim Bogu oddana, i kierowana wspomnieniami bożymi, wierzyła, że nawet męczeństwem zgrzeszy, jeżeli nie usłucha Pana, nakazującego ukrycie"101.

Sam Cyprian powołuje się nie tylko na słowa Jezusa, ale i na Jego postępowanie: „to Pan polecił uchodzić i uciekać w czasie prześladowania, i by tak było, uczył i uczynił" ${ }^{102}$. W liście ósmym również podaje wzgląd roztropności:

\footnotetext{
${ }^{98}$ Augustinus Hipponensis, Epistula 228, 4, PL 57, 486, ŹM 26, 115.

${ }^{99}$ Por. Pontius Diaconus, Vita Cypriani 7, PL 3, 1488B-C, tłum. J. Czuj, w: Św. Cyprian, Pisma i traktaty, POK 19, Poznań 1937, 63. Na temat ucieczki Cypriana zob. H. Montgomery, The Bishop who fled: Responsability and Honour in Saint Cyprian, StPatr 21 (1989) 264-267.

${ }^{100}$ Cyprianus Carthaginensis, Epistula 20, 1, PL 4, 262, PSP 1, 73. Por. tamże 16, 4, PL 4, 253 , PSP 1, 68.

${ }^{101}$ Pontius Diaconus, Vita Cypriani 7, PL 3, 1488, POK 19, 63.

${ }^{102}$ Cyprianus Carthaginensis, De lapsis 10, PL 4, 474A, tłum. J. Czuj: Św. Cyprian, O upadtych, w: Św. Cyprian, Pisma i traktaty, POK 19, Poznań 1937, 204.
} 
„Postąpiłem w ten sposób nie dlatego, abym się chciał ratować, ale ze względu na pokój braci. Po prostu, by przez nieroztropną swą obecność wybuchłego rozruchu jeszcze bardziej nie powiększać"103.

Roztropność znajduje u niego własny powód: nie chce prowokować prześladowców. Ta sama racja każe liczyć się z własną słabością i wziąć pod uwagę możliwość upadku: „kto zaś nie uchodząc upadł, został na to, by się zaprzeć"104. Zarówno pozostanie na miejscu prześladowań, jak i ucieczka, może pod pewnymi warunkami być dziełem cnoty: to pierwsze - męstwa, to drugie - roztropności. Pierwsza postawa jest wyznaniem publicznym wiary, druga - prywatnym. W przypadku confessio privata świadectwo wiary składa się nie tyle przed ludźmi, co przed Bogiem, strzegąc czystości sumienia. Rozstrzygającym motywem ucieczki nie jest lęk, bo jeśli ktoś ucieka w duchu Chrystusa, to zachowuje gotowość wyznania Go publicznie, gdyby zaszła taka konieczność ${ }^{105}$. Poncjusz wskazuje też na wiele dobra, które zdziałał Cyprian jako pasterz dzięki temu, że pozostał przy życiu aż do drugiego prześladowania w 258 r. Chroniąc swoje życie, biskup musiał brać pod uwagę rację duszpasterską: opiekę nad wiernymi, zagubionymi podczas represji i doświadczanymi przez grasujące w tym czasie epidemie, rozstrzyganie sporów związanych z powrotem upadłych do Kościoła, stawiania czoła schizmie spowodowanej przez nowacjan ${ }^{106}$. Za Waleriana w 257 r. Cyprian zostaje skazany na banicję. Po roku wraca i oczekuje przesłuchania, jednak znowu ukrywa się na jakiś czas, tym razem chwilowo. Prokonsul był wtedy nieobecny w Kartaginie i Cyprian, aresztowany, poniósłby śmierć w Uttyce. Czeka więc na powrót namiestnika, aby jeśli zajdzie konieczność śmierci męczeńskiej, ponieść ją w Kartaginie - na świadectwo dla swoich wiernych i ze względu na godność stolicy biskupiej ${ }^{107}$.

Cyprian pozostaje szczególnym teologiem ucieczki chrześcijańskiej. Znamienne, że w jego myśli jest obecna większość argumentów za ucieczką, które uchwyciliśmy w wypowiedziach innych Ojców. Być może jego czyny i słowo - bo był czytany przez potomnych - miały duży wpływ na argumentację następujących po nim pisarzy.

Zalecenie ucieczki z jednej miejscowości do drugiej, udzielone przez Jezusa w Mt 10, 23a, skłaniało starożytnych komentatorów do głębszej refleksji. Ich myśl wyrastała z realiów życia codziennego, naznaczonych groźbą prześladowań. Zbyt łatwe opuszczenie miejsca represji mogło sprawiać wrażenie

\footnotetext{
${ }^{103}$ Tenże, Epistula 20, 1, PL 4, 262, PSP 1, 73.

104 Tenże, De lapsis 10, PL 4, 474A, POK 19, 204.

105 Por. tamże 3, PL 4, 467B, POK 19, 198.

${ }^{106}$ Por. Pontius Diaconus, Vita Cypriani 7, PL 3, 1488, POK 19, 63.

${ }^{107}$ Por. Cyprianus Carthaginensis, Epistula 81, 1, PL 4, 431-432, PSP 1, 307.
} 
tchórzostwa, zbyt uparte trwanie w nim - lekkomyślności. Dyskusję nad tą kwestią prowokowały dodatkowo poglądy montanistów odrzucających możliwość ucieczki. Przedstawiliśmy powyżej poglądy Ojców greckich i łacińskich na temat rozpatrywanego zalecenia Jezusa. Refleksja Ojców jest przede wszystkim wskazywaniem racji, dla których wolno uciec.

Źródła pozwalają uchwycić następujące racje ucieczki przed prześladowaniami: 1) formalne posłuszeństwo zaleceniu Jezusa; 2) zrządzenie Opatrzności Bożej dyktujące i umożliwiające ucieczkę; 3) postawa Chrystusa, który sam korzystał z podobnej możliwości, 4) wzgląd słabości człowieka, który z różnych powodów może być niedysponowany do śmierci męczeńskiej; 5) roztropność nakazująca zbiec w przewidywaniu większych strat niż zysków poniesionych przez pozostanie; 6) zaufanie do Boga zapewniającego naturalny sposób ratunku, bez „zmuszania” Go do nadzwyczajnej pomocy; 7) pilna posługa misyjna i duszpasterska do wykonania; 8) nie prowokowanie przez swoją obecność prześladowcy do zła; 9) swoiste świadectwo wyrzeczenia i ofiary składane przez opuszczenie własnego domu i posiadłości; 10) odstąpienie od tego, co złe i nieczyste, dzięki ucieczce rozumianej duchowo.

Kilku autorów wyróżnia się w rozległości i dogłębności rozpatrywania problemu: Orygenes, Tertulian, Hieronim czy Augustyn. Na autorów IV w. i późniejszych duży wpływ mógł wywrzeć Cyprian z Kartaginy, który posądzany przez swoich oponentów, szczególnie nowacjan, uzasadnia teologicznie ucieczkę i uwiarygodnia ją późniejszą postawą: troskliwego pasterza i nieustraszonego męczennika. Jesteśmy świadkami zdumiewającej komplementarności starożytnej egzegezy, która w swojej całości tworzy bogatą tradycję interpretującą słowa Ewangelii.

\section{THE INCENTIVE TO RUNNING AWAY FROM PERSECUTION (MT 10:23A) IN THE PATRISTIC INTERPRETATION}

\section{(Summary)}

The recommendation of escape during the persecution, given by Jesus in Matth 10:23, impelled the ancient commentators to deeper reflection. Apart from the realities of the Christian life threatened by persecution, the views of the montanists rejecting the possibility of escape provoked discussion on this issue. The author of the paper has presented the thought of the Greek and Latin Fathers on this mentioned words of Jesus. The patristic reflection on Matth 10:23 points out, first of all, the reasons for fair act of fleeing. The sources allow us to enumerate the following reasons for fleeing a persecution: 1) a formal obedience to the recommendation of Jesus; 2) the decree of Divine Providence dictating and allowing escape; 3) the attitude of Christ who himself has taken similar opportunity; 4) a respect for human weaknesses that can make someone for various reasons indisposed to martyrdom; 5) a prudence ordering flee in expectation of higher losses 
than profits incurred by the remaining at home; 6) the trust in God providing a natural way of rescue, without ,forcing” Him to the extraordinary help; 7) an urgent missionary and pastoral ministry to perform; 8) to avoid provoking persecutor to evil by own presence; 9) a specific witness of renunciation and sacrifice by leaving own home and possession; 10) the escape understood in the spiritual sense is a secession from the evil and sin. Several authors stand out in the extent and the depth of reflexion about it: Origen, Tertullian, Jerome and Augustine. The authors of $4^{\text {th }}$ Century and the later could be influenced by Cyprian of Carthage. Accused by his opponents, especially novatians, he justifies theologically the escape and validates it by the later attitude: as a carefull shepherd and fearless martyr.

Key words: Mt 10:23a, escape, persecution, apostasy, martyrdom, patristic exegesis, Origen, Tertullian, Cyprian of Carthage, Jerome, Augustine

Słowa kluczowe: Mt 10, 23a, ucieczka, prześladowania, apostazja, męczeństwo, egzegeza patrystyczna, Orygenes, Tertulian, Cyprian z Kartaginy, Hieronim, Augustyn

\section{BIBLIOGRAFIA}

\section{Źródła}

Ambrosius Autpertus, Expositio in Apocalypsin, ed. R. Weber, CCM 27-27A, Turnhout 1975.

Ambrosius Mediolanensis, De fuga saeculi, ed. C. Schenkl, CSEL 32/2, Vindobonae 1897, 501-638, tłum. W. Szołdrski: Św. Ambroży, O ucieczce od świata, w: Św. Ambroży, Wybór pism, PSP 7, Warszawa 1971, 89-128.

Ambrosius Mediolanensis, De officiis, ed. M. Testard, CCL 15, Turnhout 2000, thum. K. Abgarowicz: Św. Ambroży, O obowiazkach duchownych, Warszawa 1967.

Ambrosius Mediolanensis, Explanatio psalmorum XII, ed. M. Petschenig, CSEL 64, Vindobonae 1919.

Ambrosius Mediolanensis, Expositio psalmi CXVIII, ed. M. Petschenig, CSEL 62, Vindobonae 1913.

Anastasius Sinaita, Quaestiones et responsiones, ed. J.A. Munitiz - M. Richard, CCG 59, Turnhout 2006.

Apponius, In Canticum canticorum expositio, ed. B. de Vregille - L. Neyrand, CCL 19, Turnhout 1986, 1-311.

Asterius Sophista, Commentarii in Psalmos, ed. M. Richard, Asterii sophistae commentariorum in Psalmos quae supersunt, Oslo 1956.

Athanasius Alexandrinus, Apologia ad Constantium, ed. J.M. Szymusiak, SCh 56bis, Paris 1987, tłum. J. Ożóg: Św. Atanazy, Apologia do Konstancjusza, w: Św. Atanazy, Apologie, PSP 21, Warszawa 1979, 167-188.

Athanasius Alexandrinus, Apologia de fuga sua, ed. H.G. Optiz, w: Athanasius Werke, 2/1, Berlin-Leipzig 1935, 68-86.

Athanasius Alexandrinus, Epistula encyclica, ed. H.G. Optiz, w: Athanasius Werke, 2/1, Berlin-Leipzig 1935, 169-177.

Augustinus Hipponensis, Contra Faustum, ed. J. Zycha, CSEL 25, Vindobonae 1891, thum. J. Sulowski: Św. Augustyn, Przeciw Faustusowi, PSP 55-56, Warszawa 1991. 
Augustinus Hipponensis, Contra Gaudentium, ed. M. Petschenig, CSEL 53, Vindobonae 1910.

Augustinus Hipponensis, Contra litteras Petiliani, ed. M. Petschenig, CSEL 52, Vindobonae 1909, 3-227.

Augustinus Hipponensis, De civitate Dei, ed. B. Dombart - A. Kalb, CCL 47, Turnhout 1955, thum. W. Kubicki: Św. Augustyn, Państwo Boże, Kęty 1998.

Augustinus HipPonensis, De opere monachorum, ed. J. Zycha, CSEL 41, Vindobonae 1900, 531-595, tłum. R. Szaszka: Św. Augustyn, O pracy mnichów, w: Św. Augustyn, Pisma monastyczne, ŹM 27, Kraków 2002, 187-267.

Augustinus Hipponensis, Enarrationes in Psalmos, PL 36-37, 67-1966, CCL 38-40, ed. E. Dekkers - J. Fraipont, Turnhout 1956, tłum. J. Sulowski: Św. Augustyn, Objaśnienia Psalmów, PSP 37-42, Warszawa 1986.

Augustinus Hipponensis, Epistulae, CSEL 34, 44, 57, 58, Vindobonae 1895, 1904, 1911, 1923.

Augustinus Hipponensis, In Iohannis evangelium tractatus, ed. R. Willems, CCL 36, Turnhout 1954, tłum. J. Sulowski: Św. Augustyn, Homilie na Ewangelię św. Jana, PSP 15/1-2, Warszawa 1977.

Augustinus Hipponensis, Sermones, PL 38-39.

Barsanuphius et JoAnnes, Quaestiones et responsiones ad laicos et episcopos, ed. P. Neyt P. de Angelis-Noah - L. Regnault, SCh 426, 427, 450, 451, 468, Paris 1997, 1998, 2000, 2000, 2002, thum. E. Dąbrowska: Barsanufiusz i Jan, Listy, ŹM 69, Kraków 2014.

Basilius Caesariensis, Asceticon magnum, PG 31, 1052-1305, thum. J. Naumowicz: Św. Bazyli Wielki, Reguły dłuższe, w: Św. Bazyli Wielki, Pisma ascetyczne, t. 2, ŹM 6, Kraków 1995, 41-181.

Basilius Caesariensis, Asceticon parvum, ed. K. Zelzer, CSEL 86, Vindobonae 1986, 5-221, thum. J. Naumowicz: Św. Bazyli Wielki, Reguty krótsze, w: Św. Bazyli Wielki, Pisma ascetyczne, t. 2, ŹM 6, Kraków1995, 185-453.

Beda Venerabilis, Expositio actuum apostolorum, ed. M.L. Laistner, CCL 121, Turnhout 1983, 3-99.

Beda Venerabilis, Homeliarum evangelii libri II, ed. D. Hurst, CCL 122, Turnhout 1955 , $1-378$.

Beda Venerabilis, In Lucae evangelium expositio, ed. D. Hurst, CCL 120, Turnhout 1960, $5-425$.

Beda Venerabilis, In Marci evangelium expositio, ed. D. Hurst, CCL 120, Turnhout 1960, 431-648.

Beda Venerabilis, In proverbia Salomonis libri III, ed. D. Hurst, CCL 119B, Turnhout 1983, 23-163.

Beda Venerabilis, Vita sancti Felicis, PL 94, 789-798.

Clemens Alexandrinus, Fragmenta varia, ed. O. Stählin - L. Früchtel - U. Treu, GCS 17 , Berlin $1970^{2}, 224-230$.

Clemens Alexandrinus, Stromata, ed. O. Stählin - L. Früchtel, GCS 52 (I-VI), Berlin 1960³, GCS 17 (VII-VIII), Berlin 1970², 3-102, thum. J. Niemirska-Pliszczyńska: Klemens Aleksandryjski, Kobierce zapisków filozoficznych dotyczqcych prawdziwej wiedzy, t. 1-2, Warszawa 1994.

Constitutiones Apostolorum, w: Konstytucje apostolskie, opr. A. Baron - H. Pietras, thum. S. Kalinkowski, ŹMT 42 = SCL 2, Kraków 2007, 1-293.

Cyprianus Carthaginensis, De lapsis, PL 4, 465-478, thum. J. Czuj: Św. Cyprian, O upadłych, w: Św. Cyprian, Pisma i traktaty, POK 19, Poznań 1937, 194-223. 
Cyprianus Carthaginensis, Epistulae, ed. F. Diercks, CCL 3B-C, Turnhout 1994-1996, tłum. W. Szołdrski: Św. Cyprian, Listy, PSP 1, Warszawa 1969.

Cyrillus AleXandrinus, Commentarii in Matthaeum, PG 72, 365-474.

Cyrillus Alexandrinus, Glaphyra in Pentateuchum, PG 69, 9-678.

Eusebius „Gallicanus”, Collectio homiliarum, ed. F. Glorie, CCL 101A, Turnhout 1971.

Eusebius Caesariensis, Commentarii in Psalmos, PG 23, 441-1221.

Eusebius Caesariensis, Historia ecclesiastica, ed. E. Schwartz, GCS 9/2, Leipzig 1908, tłum. A. Lisiecki: Euzebiusz z Cezarei, Historia kościelna, POK 3, Poznań 1924.

Facundus Hermianensis, Pro defensione trium capitum libri XII ad Iustinianum, ed. I.M. Clément - R. Vander Plaetse, CCL 90A, Vindobonae 1974, 3-398.

Gregorius Magnus (?), In librum primum Regum expositionum libri VI, ed. P. Verbraken, CCL 144, Turnhout 1963, 49-614.

Gregorius Nazianzenus, Orationes, ed. J. Bernardi, SCh 309, Paris 1983, thum. zbiorowe: Święty Grzegorz z Nazjanzu, Mowy wybrane, Warszawa 1967.

Hieronymus, Commentarii in evangelium Matthaei, ed. D. Hurst - M. Adriaen, CCL 77, Turnhout 1969, thum. J. Korczak: Hieronim ze Strydonu, Komentarz do Ewangelii wedlug św. Mateusza, ŹMT 46, Kraków 2008.

Hieronymus, In Hieremiam prophetam libri VI, ed. S. Reiter, CSEL 59, Vindobonae 1913.

Joannes Cassianus, Collationes XXIII, ed. M. Petschenig, CSEL 13, Vindobonae 1886, thum. A. Nocoń: Jan Kasjan, Rozmowy z Ojcami, t. I. Rozmowy I-X, ŹM 28, Kraków 2002.

Joannes Chrysostomus, De sanctis Bernice et Prosdoce, PG 50, 629-640.

Leontius Neapolitanus, Vita Joannis Eleemosynarii episcopi Alexandrini, ed. A.J. Festugière - L. Rydén, Léontios de Néapolis, Vie de Syméon le Fou et Vie de Jean de Chypre, Paris 1974.

Origenes, Commentarii in Matthaeum (fragmenta), ed. E. Klostermann - E. Benz, GCS 41/1, Leipzig 1941, 13-235.

Origenes, Commentarii in Matthaeum, ed. E. Klostermann - E. Benz, GCS 38, 40, Leipzig 1933, 1935, tłum. K. Augustyniak: Orygenes, Komentarz do Ewangelii wedtug św. Mateusza, ŹMT 10, Kraków 1998.

Origenes, Contra Celsum, ed. M. Borret, SCh 132, 136, 147, 150, Paris 1967-1969, thum. S. Kalinkowski: Orygenes, Przeciw Celsusowi, Warszawa $1986^{2}$.

Origenes, Homiliae in librum Iudicum, ed. W.A. Baehrens, GCS 30, 464-522, thum. S. Kalinkowski: Orygenes, Homilie o Księdze Sędziów, w: Orygenes, Homilie o Księgach Liczb, Jozuego, Sędziów, PSP 34/2, Warszawa 1986, 139-185.

Origenes, In Iesu Nave homiliae, ed. W.A Baehrens, GCS 30, Leipzig 1921, 286-463, thum. S. Kalinkowski: Orygenes, Homilie o Księdze Jozuego, w: Orygenes, Homilie o Księgach Liczb, Jozuego, Sędziów, PSP 34/2, Warszawa 1986, 3-137.

Origenes (?), Fragmenta e catenis in Psalmos, ed. J.B. Pitra, Analecta sacra, t. 3, Venetiis 1883, passim 4-364.

Orosius, Historiarum adversum paganos libri VII, PL 31, 635-1214.

Palladius, Dialogus de vita Joannis Chrysostomi, ed. P.R. Coleman-Norton, Cambridge 1928.

Passio Agapes et Eirenes et Chiones, ed. H. Musurillo, w: The acts of the Christian martyrs, Oxford 1972, 280-292.

Passio Quirini, ed. Th. Ruinart, w: Acta Martyrum, Ratisbonae 1859, 522-524.

Petrus Alexandrinus, Epistula canonica, ed. M.J. Routh, Reliquiae sacrae, t. 4, Oxonii $1846^{2}, 23-45$.

Petrus Chrysologus, Collectio sermonum, ed. A. Olivar, CCL 24B, Turnhout 1975. 
Pontius Diaconus, Vita Cypriani, PL 3, 1481-1541, tłum. J. Czuj, w: Św. Cyprian, Pisma, t. 1. Traktaty, POK 19, Poznań 1937, 56-75.

Possidius, Vita Augustini, 30, PL 32, 33-64, tłum. P. Nehring: Possydiusz, Żywot św. Augustyna, ŹM 26, Kraków 2002, 111-126.

Procopius Gazaeus, Catena in Esaiam, PG 87/2, 1817-2718.

Socrates Scholasticus, Historia ecclesiastica, PG 67, 33-841, thum. S. Kazikowski: Sokrates Scholastyk, Historia Kościoła, Warszawa 1972.

Sozomenos, Historia ecclesiastica, PG 67, 844-1629, tłum. S. Kazikowski: Hermiasz Sozomen, Historia Kościoła, Warszawa 1989.

Tertullianus, Ad uxorem, ed. E. Kroymann, CCL 1, Turnhout 1954, 373-394, thum. K. Obrycki: Tertulian, Do żony, w: Tertulian, Wybór pism II, PSP 29, Warszawa 1983, 147-164.

Tertullianus, De fuga in persecutione, ed. J.J. Thierry, CCL 2, Turnhout 1954, 1135 1155, tłum. T. Kołosowski: Tertulian, O ucieczce podczas prześladowań, w: Tertulian, Wybór pism III, PSP 65, Warszawa 2007, 153-174.

Tertullianus, De patientia, ed. J.G. Borleffs, CCL 1, Turnhout 1954, 299-317, tłum. E. Stanula: Tertulian, O cierpliwości, w: Tertulian, Wybór pism, PSP 5, Warszawa $1970,155-174$.

Verecundus Iuncensis, Commentarii super cantica ecclesiastica. In canticum Hieremiae, ed. R. Demeulenaere, CCL 93, Turnhout 1976, 3-203.

Opracowania

McDermott J.-M., Matth 10: 23 in context, „Biblische Zeitschrift” 28 (1984) fasc. 2, 230-240.

Montgomery H., The Bishop who fled: Responsability and Honour in Saint Cyprian, StPatr 21 (1989) 264-267.

Ostrowski H., Wiara a męczeństwo w „Dywanach” Klemensa Aleksandryjskiego, VoxP 8 (1988) t. 15, 629-633.

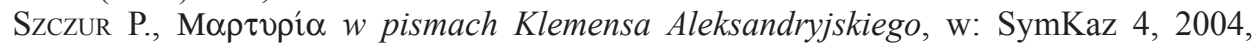
97-109. 